\title{
Credit Lines: The Other Side of Corporate Liquidity
}

\author{
Filippo Ippolito \\ Universitat Pompeu Fabra \& Barcelona GSE \\ filippo.ippolito@upf.edu
}

\author{
Ander Perez ${ }^{1}$ \\ Universitat Pompeu Fabra \& Barcelona GSE \\ ander.perez@upf.edu
}

March 21, 2012

\begin{abstract}
In this paper we offer the first large sample evidence on the availability and usage of credit lines in U.S. public corporations and use it to re-examine the existing findings on corporate liquidity. We show that the availability of credit lines is widespread and that average undrawn credit is of the same order of magnitude as cash holdings. We test the trade-off theory of liquidity according to which firms target an optimum level of liquidity, computed as the sum of cash and undrawn credit lines. We provide support for the existence of a liquidity target, but also show that the reasons why firms hold cash and credit lines are very different. While the precautionary motive explains well cash holdings, the optimum level of credit lines appears to be driven by the restrictions imposed by the credit line itself, in terms of stated purpose and covenants. In support to these findings, credit line drawdowns are associated with capital expenditures, acquisitions, and working capital.
\end{abstract}

JEL Classifications: G30, G31, D22

Keywords: cash holdings, credit lines, lines of credit, revolving credit facilities, tradeoff theory, liquidity, financial constraints, covenants

\footnotetext{
${ }^{1}$ Contact details: Departament d'Economia i Empresa, Universitat Pompeu Fabra, Ramon Trias Fargas, 25-27, 08005 Barcelona.
} 


\title{
Credit Lines: The Other Side of Corporate Liquidity
}

February 29, 2012

\begin{abstract}
In this paper we offer the first large sample evidence on the availability and usage of credit lines in U.S. public corporations and use it to re-examine the existing findings on corporate liquidity. We show that the availability of credit lines is widespread and that average undrawn credit is of the same order of magnitude as cash holdings. We test the trade-off theory of liquidity according to which firms target an optimum level of liquidity, computed as the sum of cash and undrawn credit lines. We provide support for the existence of a liquidity target, but also show that the reasons why firms hold cash and credit lines are very different. While the precautionary motive explains well cash holdings, the optimum level of credit lines appears to be driven by the restrictions imposed by the credit line itself, in terms of stated purpose and covenants. In support to these findings, credit line drawdowns are associated with capital expenditures, acquisitions, and working capital.
\end{abstract}

JEL Classifications: G30, G31, D22

Keywords: cash holdings, credit lines, lines of credit, revolving credit facilities, tradeoff theory, liquidity, financial constraints, covenants 


\section{Introduction}

Corporate liquidity is typically identified in the empirical corporate finance literature with cash holdings, which include cash instruments and short-term liquid investments. Clearly cash holdings are not the only source of liquidity as firms can generate cash by liquidating assets, by drawing down on lines of credit, by hoarding internally generated cash flows, and by raising external finance. But all of these potential sources of liquidity, except for lines of credit, critically differ from cash in that they do not offer the same flexibility and safety as cash holdings. Future internal cash flows are risky, external finance may not be available or may be too costly, and asset liquidations are not guaranteed to provide a certain amount of liquidity in the future. The only source of liquidity that offers the same degree of flexibility and safety as cash are drawdowns on available credit lines, and this suggests that they should be studied jointly.

Limited data availability on credit lines has made it difficult for the empirical literature on corporate liquidity to extend the focus beyond cash holdings. In this paper, we take advantage of Capital IQ to provide the first large sample evidence on credit lines for U.S. public firms. The sample reveals that over the period 2002-2008, firms have made a widespread use of credit lines, with two thirds of public U.S. corporations holding a credit line. The percentage of firms with a credit line rises to over $80 \%$ for firms that have assets greater than $\$ 1$ bn (Figure 1). On average (undrawn) credit lines amount to $13.4 \%$ of assets and are of similar magnitude as cash holdings (14.1\% of assets). While smaller firms mainly hold their liquidity as cash, larger firms rely primarily on credit lines (Figure 2).

We use this database to reexamine several key issues regarding liquidity, both in relation to the optimum amount of liquidity and to the motivations that drive firms to hold liquid assets. Historically, U.S. corporations have held significant amounts of cash, well beyond what is needed for managing current operations. As shown by Bates, Kahle and Stulz (2009) since 1980 U.S. corporations have further increased their cash holdings, such that in 2006 cash holdings were so large that the average firm could retire all debt obligations. The 
size of cash holdings has led researchers to investigate the reasons why firms accumulate liquidity.

Opler, Pinkowitz, Stulz, and Williamson (1999) (OPSW henceforth) propose a trade-off theory of cash according to which firms optimize the level of cash they hold by trading off the benefits and costs. Among the costs of holding liquid assets are lower rates of return due to a liquidity premium and tax disadvantages. However, liquid assets have two main benefits. First, firms that hold liquid assets can reduce transaction costs to make payments as they do not need to liquidate their existing (possibly firm specific) assets. Second, firms can rely on liquid assets to finance their activities and to make investments when other sources of capital cannot be raised (possibly due to financial constraints) or are too costly. The first of these reasons for holding liquid assets is known as the transaction motive, while the second reason is normally referred to as the precautionary motive. The trade-off theory of cash predicts an optimum amount of cash, towards which firms tend to revert if they hold too little or too much cash. OPSW test the hypothesis and provide supportive evidence for readjustment towards an optimum level of cash holdings. They also show that firm characteristics, such as market-to-book, size, R\&D investments, that are associated with the transaction and precautionary motives are also related to cash holdings.

To evaluate the trade-off theory for a measure of liquidity that accounts for cash and undrawn credit lines we need to assess the benefits and costs of hoarding liquidity in the form of credit lines. The benefits of having available credit are essentially the same as having cash holdings, and consist primarily in the immediacy of available liquidity at low cost. Credit lines and cash differ mainly along two dimensions. First, credit lines are normally issued with a stated purpose which restricts their possible uses. In our sample the majority of credit lines carries a precise stated purpose, the most common being acquisitions, capital expenditures, refinancing and working capital. Second, credit lines have a predetermined maturity. This implies that any drawn amount has to be repaid before the credit line matures, thus limiting the use of credit lines for example for long term investments. In our sample, around $20 \%$ of 
credit lines come in the form of 364-day facilities or revolvers with maturity of less than one year. The remaining credit lines typically mature within six years from the time of issue.

Credit lines generate direct costs in the form of fees on the outstanding amount of undrawn credit. And, perhaps more importantly, credit lines carry indirect costs associated with the restrictions that banks impose to firms via the inclusion of covenants in the credit agreement. In our sample we find that the majority of credit lines carry one or more covenants. Typically covenants impose restrictions on leverage and interest coverage ratios, impose profitability levels, liquidity and collateral requirements, and cash flow sweeps. As a result of these covenants, firms may be prevented from achieving their optimal capital structure and investment policy.

Following the procedure of OPSW we test the trade-off theory of liquidity in a dynamic framework. We define liquidity as the sum of cash holdings and (undrawn) credit lines and construct several definitions of target liquidity, respectively based on market, industry and year median liquidity levels. We then estimate whether firms that are off the target in one year adjust their liquidity in the following year so to be closer to target. We repeat the same procedure and construct a target level for cash holdings and (undrawn) credit lines. Our results confirm the idea that a target exists for each of these variables. Liquidity, cash holdings and credit lines all show a negative relation with the distance from the target. Year on year liquidity adjusts by $35.7 \%$ of its distance from target, and this is due to an adjustment of $20.1 \%$ in cash and $14.9 \%$ in (undrawn) credit lines. Cash adjusts by $26.7 \%$ towards target and (undrawn) credit lines by $41.6 \%$.

We then predict the optimum firm liquidity level by relating each of our liquidity variables to firm characteristics. The transactions motive identifies size as the main proxy for transaction costs and predicts size to be inversely related to the amount of liquidity a firm holds. The precautionary motive suggests that firms that are more financially constrained due to higher agency costs between shareholders and managers should hold more liquid assets. Common proxies for agency costs and financial constraints include size, market-to- 
book, tangibility and whether the firm pays dividends or not.

Our estimation provides support to both the transaction and precautionary motive for the use of cash and for overall liquidity. Firms that are smaller, with higher market-tobook, and less tangible tend to have both more cash holdings and more liquidity holdings. ${ }^{2}$ However, we obtain exactly the opposite signs for the coefficients associated with reliance on (undrawn) credit lines (intensive margin of credit lines). Heavy users of credit lines tend to be better firms: firms that are more profitable, with lower market-to-book and pay dividends. Less financially constrained and with lower beta tend to have more credit lines than the rest. This may suggest that the estimation of the intensive margin is affected by the fact that more financially constrained firms cannot access a credit line in the first place. To dispel this argument, we carry out further estimations based on the subsample of firms that have a credit line and are rated investment grade. Our results remain strong also in this subsample of financially unconstrained firms.

Our results therefore provide a direct contradiction of the use of credit lines for precautionary motives and indicate that firms in better financial conditions are the main users of credit lines. One possible interpretation of these findings is that only firms in healthy conditions can meet the requirements imposed by the covenants attached to the credit lines. This interpretation provides then support to the argument of Sufi (2009) on the revocability of these credit agreements.

If the stringency of the credit agreement affects the extent to which firms rely on credit lines, it is reasonable to expect that not only the attached covenants matter but also the stated purpose of the credit line. Accordingly, we examine the relationship between changes in several financial variables that are stated as possible purposes for the credit line, and variations in (undrawn) credit lines. We find that the change in inventories, acquisition

\footnotetext{
${ }^{2}$ One may question whether it is reasonable to draw inferences about the effect that firm characteristics have on liquidity by looking at the coefficients of a regression in which cash is the dependent variable. This result however depends crucially on whether we consider all cash holdings to be the relevant measure of available liquidity in the form of cash, or we distinguish between operational and non-operational cash. Using non-opearational cash we confirm the results obtained using the standard measure of cash.
} 
expenses, capital expenditures, and changes in account receivables, are all negatively related to the change in undrawn credit lines, and correspondingly positively related to the change in drawn credit lines (which are part of debt). This evidence suggests that stated purposes matter for the use of credit lines. Our findings provide support to the thesis of Lins, Servaes and Tufano (2010) that the choice is driven by the different uses of cash and credit lines. Undrawn credit is used to invest in future business opportunities, while cash serves a more general purpose and is used to hedge against negative cash flow shocks.

Next we assess which firms have a credit line, i.e. we provide an estimate of the extensive margin of credit lines. This step is not required when one studies cash, because to some extent all firms can access cash. The literature has advanced several hypotheses for which firms are more likely to employ credit lines. Sufi (2009) argues that only profitable firms can rely on credit lines, as these can be revoked when a covenant violation occurs. Financial constraints also play a role, and firms that are more financially constrained find it difficult to access a credit line. Acharya, Almeida and Campello (2010) suggest that banks are unwilling to offer lines of credit to firms that are exposed to more systematic risk. In Yun (2009) firms with worse corporate governance are more exposed to managerial opportunism associated with cash holdings (Jensen (1986)) and rely more on credit lines. Finally, firms with more seasonal businesses may rely on credit lines to smooth within year variations in cash flows.

We estimate an empirical specification that encompasses all the above explanations for the use of credit lines and show that, with the exception of seasonality, each of these explanations is confirmed by the data. More importantly, the factors affecting the extensive margin are the same ones that affect the intensive margin which supports the idea that the requirements imposed in a credit line, in terms of financial ratios, affect similarly both access and amounts of credit lines. Overall, these findings indicate that only healthy firms can rely on credit lines as their primary source of liquidity.

As a final step, we investigate deeper the relationship between cash holdings and credit 
lines. As discussed above, these two sources of liquidity are not perfect substitutes because credit lines are subject to restrictions that do not apply to cash. However, sorting firms with respect to their cash holdings produces a clear inverse variation in (undrawn) credit lines, which suggests a certain degree of substitutability between the two sources of liquidity. This result is reassuring in that it provides support to the idea that credit lines are an alternative source of liquidity besides cash. Next, we explore the reciprocal cross-sensitivity of cash and credit lines, by relating the distance from target for cash to the change in (undrawn) credit lines and viceversa. We find that the variation in credit lines is unrelated to the distance from the optimum cash level. On the contrary, firms with excessive undrawn credit in a given year tend to increase cash in the following year, and this occurs precisely because they draw down on their lines of credit.

The rest of the paper is structured as follows. In Section 2 we discuss the sample construction. In Section 3 we present large sample evidence on the typical characteristics of a credit line. Section 4 provides tests on the trade-off theory of liquidity, while Section 5 relates firm characteristics to observed liquidity levels. Section 6 investigates which firms have access to a credit line. Section 7 examines the cross-sensitivity of cash and credit lines. Finally, Section 6 concludes.

\section{Sample Construction}

We obtain firm-level data from the Capital IQ (CIQ) and Compustat databases for the period of 2002-2008. We restrict ourselves to U.S. firms covered on both databases and traded on AMEX, NASDAQ, or NYSE. We remove utilities (SIC codes 4900-4999) and financial firms (SIC codes 6000-6999). Following Bates et al. (2009), we further remove firm-years with negative revenues, and negative or missing assets, obtaining in the end a sample of 23,013 firm-years involving 4,248 unique firms.

CIQ compiles detailed information on capital structure and debt structure by going 
through financial footnotes contained in firms' 10K Securities and Exchange Commission (SEC) filings. Most importantly for our purposes, firms provide detailed information on the drawn and undrawn portions of their credit lines in the liquidity and capital resources section under the management discussion, or in the financial footnotes explaining debt obligations, and CIQ compiles this data. 10K filings typically also contain information on pricing and maturity of credit lines, but this data is not collected by CIQ. We use the information of CIQ to construct a dummy for the presence of a credit line, which is equal to one if the firm has a positive amount of credit lines reported in the 10K. Following Sufi (2009) we also construct a measure of the amount of credit lines expressed as a percentage of book assets (Compustat item 6). As in Bates, et al. (2009), Opler, et al. (1999), Almeida, et al. (2004) and Acharya, et al. (2010) we compute the ratio of cash and investments (item 1) over total assets (item 6). We then add credit lines from CIQ and cash and investments (item 1) and divide the sum by assets (item 6) to obtain our main measure of liquidity.

Following Bates, et al. (2009), we also compute the variables that are known to be relevant for cash holdings behavior. Size is the logarithm of assets (item 1), where assets are expressed in millions of 2001 dollars deflated by the consumer price index. Net working capital to assets is computed as the difference between working capital (item 179) and cash and investments (1) divided by assets (item 6). R\&D expenses are computed as the ratio of research and development expenses (item 46) over sales (item 12). Book leverage is debt in current liabilities (item 34) plus long-term debt (item 9) over assets (item 6). Industry cash-flow risk (named industry sigma) is the mean cash-flow volatility computed by twodigit SIC code. Cash-flow volatility is the standard deviation of operating income before depreciation (item 13) calculated over the previous twelve quarters and scaled by assets (item 6). Dividend payout dummy is a dummy that takes value of one if common stock has paid dividends (item 21). Acquisition expenses are computed as acquisitions (item 129) over assets (item 6).

Following Lemmon, et al. (2008), we compute the M/B ratio as the sum of the market 
value of equity, total debt, and preferred stock at liquidating value (item 10), minus deferred taxes and investment tax credit (item 35), all divided by assets (item 6). Market value of equity is computed as stock price (item 199) times number of common shares used to calculate the earnings per share (item 54). Total debt is current liabilities (item 34) plus long-term debt (item 9). Industry profitability is the average profitability computed by twodigit SIC code. Profitability is operating income before depreciation (item 13) over assets (item 6). Tangibility is net property, plant and equipment (item 8) over assets (item 6).

We also compute firm-year rating as the average monthly rating by S\&P (item 280), after converting the $\mathrm{S} \& \mathrm{P}$ rating into numbers. Credit spread is the spread on U.S. corporate bond yields between Moody's AAA and BAA provided by Datastream, based on averages of seasoned issues. Finally, following standard procedures, all variables are winsorized at the $0.5 \%$ in both tails of the distribution. A summary of these variables can be found in Table A1.

In Table A2 we compare our sample to the Compustat sample and show that our sample is representative of the Compustat sample along the main variable of interest in our analysis, namely cash holdings. The two samples are also similar in terms of book leverage, market-to-book, cash flow/ assets. The two samples differ in terms of firm size (as measured by book value of assets) and percentage of rated firms.

Finally, we collect information on the characteristics of credit lines from LPC Dealscan. The sample comprises 13.115 credit lines issued between 2002-2008 to the firms in the sample covered by Capital IQ and Compustat. Among other, LPC Dealscan contains information on stated purpose, covenants, spreads, and type of facility.

\section{The characteristics of a credit line}

In this section we examine the characteristics of a credit line in terms of fees, maturities, stated purposes, and covenants. 
Fees Keeping an open credit line with a bank requires the payment of a fee on the undrawn amount. Sufi (2009) estimates that these costs amount to 25 basis points. The price of credit lines (when drawn) is typically expressed in terms of spread over a reference rate that can be LIBOR or the prime rate, and is normally in the range of 100-400 basis points. Spreads have changed significantly over the period of observation, as is illustrated in Figure 3. The average spread over the period is 233 basis points (median 200 basis points).

Maturities Figure 4 shows that credit lines come primarily in the form of revolvers, according to which a firm can drawdown part of the available credit and pay it back any time before maturity. The capital that is repaid can then be drawn down at a later time. An important dimension along which the various types of credit lines differ is maturity. As shown in Figure 5 we observe significant variation in maturity. The maturity of most lines coincides with a multiple of 12 months. We observe that $18.72 \%$ of lines have a maturity of 12 months, $4.59 \%$ of 24 months, $15.31 \%$ of 36 months, $3.83 \%$ of 48 months, $21,89 \%$ of 60 months, $2.67 \%$ of 72 months, and $2.3 \%$ of 84 months. With reference to Figure 4 , revolver lines with maturity of less than year have an average maturity of 8.14 months, 364-day facilities have a maturity of 12.26 months, revolver lines with maturity over one year mature on average in 45.29 months, and revolver loans mature on average in 69.72 months.

Stated purposes There are limitations in how managers can use a credit line as these are normally issued with a contractual specification of stated purpose. Figure 6 illustrates the different types of purposes that we observe in our sample and they include: acquisitions, capital expenditure, refinancing, working capital, and general corporate purposes. As in most cases a credit line carries two purposes, the figure illustrates the distribution of both purposes. ${ }^{3}$ Figure 6 shows that more than $80 \%$ of firms carry general corporate purposes as one of the purposes, which suggests that most firms are not significantly restricted in the expenditures they can finance using lines of credit, unless other contractual restrictions in

\footnotetext{
${ }^{3}$ It is worth noticing that the order of purposes does not imply hierarchy between purposes.
} 
addition to the stated purpose specify such limitations.

Covenants As discussed in Sufi (2009), most credit lines carry covenants that typically impose restrictions on one or more financial ratios. In the sample we observe that $58.92 \%$ of credit lines have at least one covenant, and there are significant variations in the covenants

included in the credit agreements. As shown in Table 1, common covenants include primarily restrictions along five dimensions. A set of covenants restricts the freedom of managers to increase leverage excessively or to reduce the interest coverage ratio. The most common of these covenants is a limitation on the ratio between outstanding debt and EBITDA. Some covenants impose requirements on liquidity ratios, the most common being the quick and current ratios, or on capital expenditures. Some covenants impose collateral and profitability requirements. Finally, other covenants impose sweeps on the cash flows of the firm which require repayment of principle from a portion of the proceeds of the new debt issuance.

Figure 7 illustrates the evolution of the use of covenants over time. We construct an index that is the sum of all the covenants contained in a credit line and then average this index on a monthly basis. The figure illustrates how the use of covenants has reduced significantly from the first half of the sample to the second half. The use of covenant lite agreements becomes common from 2006 onwards.

\section{Tests of the trade-off theory of liquidity}

The trade-off theory of cash as proposed by OPSW relies on the idea that firms have a desired amount of cash which is obtained by balancing the benefits and costs of holding liquid assets in portfolio. We now propose an extension of this theory to include not only cash but also (undrawn) credit lines. The benefits of credit lines are similar to those offered by cash holdings, subject to the restrictions imposed by the stated purpose of the credit line and its maturity. Credit lines generate direct costs in the form of fees on the undrawn amounts, and indirect costs due to the limitations imposed on the actions of the firm by the 
covenants that the credit line carries.

Therefore, the trade off theory of liquidity as we propose it here, predicts that there is an optimum level of (undrawn) credit lines that firms try to achieve, where the optimum is obtained by balancing the benefits and costs of the line. As cash also has an optimum level, liquidity computed as the sum of cash and credit lines, must also have an optimum level.

Following OPSW a test of the trade off theory can be constructed around the idea that if a firm is not on target in one year, in the next one it will try to get closer to the target. This theory and its implications resemble closely those of the trade off theory of capital structure (Lemmon, Roberts and Zender (2008), Leary and Roberts (2005), Flannery and Rangan (2006)). As it happens for capital structure, in the presence of frictions we may expect the adjustment towards the optimum level of liquidity not to occur instantaneously but slowly over time (partial adjustment).

A test of the trade off theory of liquidity relies fundamentally on the existence of a target and on mean reversion towards this target over time. We construct four different measures of target for each of the three liquidity variables (cash, undrawn credit lines, and liquidity). The first measure is computed as the average liquidity in the sample; the second is the average liquidity of the industry to which a firm belongs, using three digit SIC codes; the third measure is the same as the previous one but at the two digit SIC code; the fourth measure is the average liquidity across all firms in a given fiscal year. For each of these measures we compute the difference between the observed liquidity and the target. This difference gives us the distance (with sign) from the optimum. For each liquidity variable we then construct the difference year on year and relate it to the distance from the target.

The results of our estimation are provided in Table 2 which contains a set of regressions with various combinations of liquidity variables and liquidity targets. We run the regressions in a multivariate setting controlling for several firm characteristics and fixed effects. Column 1 examines the relationship between change in liquidity in year $t$ and the distance from the optimum in year $t-1$. Column 2 and 3 repeat the same exercise using change in cash holdings 
and change in (undrawn) credit lines as a left hand side variable instead of liquidity. Column 1 reveals that the change in liquidity is inversely related to the distance (with sign) from the target. In other words, firms that have excess liquidity in year $t-1$ reduce their liquidity holdings in year $t$. From columns 2 and 3 we see that both cash holdings and undrawn credit lines diminish when there is excess liquidity in the previous year. Each year the change in liquidity is $35.7 \%$ of the distance from target, the adjustment is covered by cash in a proportion of $20.8 \%$ and by credit lines in the proportion of $14.9 \%$.

In the last two columns we examine the relationship between changes in cash and the distance from target cash holdings, and the relationship between changes in credit lines and the distance from target credit lines. The coefficients relating to the target adjustments are significant and negative in both cases. This indicates that both cash and credit lines have an optimum level towards which firms revert over time.

In the appendix in Table A3 we provide a series of robustness checks. We replicate the specifications of Table 2 using different measures of target for each of the three liquidity variables. Across all the various specifications the results provided in Table 2 appear robust.

\section{Factors that determine the amount of credit lines}

Next we examine how firm characteristics relate to liquidity. The main aim of this section is to illustrate that cash holdings, credit lines, and liquidity are associated to firm characteristics in significantly different ways. We start with the standard cash regression that is used in the literature (Opler, et al. (1999), Bates et al. (2009)) in which the ratio of cash to assets is the dependent variable and firm characteristics are the independent variables. We then extend this regression to different measures of liquidity. We consider two other measures: the ratio of credit lines to assets, and the ratio of liquidity to assets, where liquidity is defined as the sum of cash and credit lines.

The existing literature proposes several explanations for the use of credit lines. Acharya, 
Almeida and Campello (2010) suggest that a firm's aggregate risk is an important determinant of whether it manages its future liquidity needs through cash or credit lines. As banks create liquidity by pooling the idiosyncratic risk of firms, it is more difficult for firms with high aggregate risk to obtain a credit line. Sufi (2009) stresses the importance of firm profitability in determining whether it obtains access or not to a credit line. Sufi argues that lines are frequently revoked due the violation of the covenants that they carry, which are mainly based on cash-flow measures. Firms with poor past or expected cash flows face a high probability of losing access to credit lines and have to rely more on cash holdings. ${ }^{4}$ Yun (2009) suggests that in a firm with strong internal governance, shareholders are not exposed to managerial opportunism due to the large discretion offered by cash when held as a liquidity reserve. However, in firms with weak internal governance, shareholders need to limit management's discretion by reducing cash and managing liquidity primarily via credit lines, which are monitored by banks and are subject to covenants. Therefore, Yun predicts a positive relationship between governance and the use of cash as a source of liquidity, and a negative relationship between governance and the use of credit lines. Another explanation is based on seasonality in cash flows. Firms in different lines of business are exposed to the fluctuations of cash flows due to seasonal components of the economic cycle. This is clearly the case for agriculture, fishing and forestry, as well as for hotels and other businesses that rely on tourism.

Empirically it is difficult to determine whether each of the above explanations drives demand for credit lines, or instead affects the supply of credit by banks. Banks may be reluctant to commit a credit line to small firms, firms without a rating, and firms with exposed to high systematic risk. Thus, one way to look at the low reliance on credit lines for these classes of firm is that they are financially constrained and do not have access to credit lines. An alternative view is that these classes of firms have a low demand for credit lines,

\footnotetext{
${ }^{4}$ Jimenez, Lopez and Saurina (2008) also study the patterns of credit line drawdowns, and find that firms that eventually default are heavy users of lines of credit, while large and profitable firms draw down on their lines of credit less. Ex-post, firms that have suffered from financial distress in the past do not (or are not allowed to) access their lines of credit often.
} 
because lines for them are too costly.

Our findings on the determinants of liquidity are displayed in Table 3. In column 1 we examine the determinants of cash holdings, expressed as a percentage of the book value of assets. In line with the transaction motive, we find that size is negatively related to the use of cash. Insofar as part of transaction costs are fixed, larger firms can more easily overcome these costs. The negative relationship of size and cash holdings is also compatible with the precautionary motive, as larger firms tend to be less financially constrained. The positive sign of profitability and the negative signs of market to book, tangibility and dividend payer are all consistent with the precautionary motive. In column 2 we examine the relationship between (undrawn) credit lines and various firm characteristics. With the exception of size (which is not significant), the coefficients of the right hand side variables are precisely the opposite than the ones for cash. In column 3 we replicate the same exercise for liquidity and observe that the coefficients of liquidity generally take the same sign as in column 1, with the only exception of dividend payer. These findings suggest that cash and credit lines are determined by different models, and the effect on liquidity is generally dominated by the coefficients of cash, rather than credit lines. ${ }^{5}$

One may question whether the difference in sign between the coefficients of cash and credit lines is driven by a mechanical relationship in the construction of the variables. To obtain standard measures across firms, credit lines are expressed as a percentage of book value, which include cash holdings. To the extent that credit lines and cash are substitute forms of liquidity, a mechanical relationship between the two measures may arise due to the standardization. To check if this is the case, in column 4 we estimate the coefficients for credit lines by scaling for non-cash assets, which are defined as book value of assets minus cash and short term investments (item 1). The results of column 4 confirm the findings of

\footnotetext{
${ }^{5} \mathrm{~A}$ possible objection to this conclusion is that cash dominates credit lines because we use a definition of cash that includes short term investments (Compustat CHE, item 1). Instead, one may argue that we should employ a measure of non-operating cash. In Table A4 in the appendix we run the regressions presented in Table 3 using a measure of cash computed as cash and short term investments (CHE item 1) minus cash (CH item 162). The results on the coefficients of liquidity are broadly consistent with those presented in Table 3.
} 
column 2, thus suggesting that the difference in signs is not due to a mechanical effect.

The results from column 2 suggest that the intensive margin of credit lines may be driven by financial constraints that firms face in accessing a credit line. Therefore, one plausible conclusion from the results of column 2 of Table 3 is that the sign associated with the intensive margin are merely the result of financial constraints. To dispel this explanation we examine firms that are not (or less) financially constrained. In column 5, 6 and 7 we restrict the sample respectively to firms with a credit line, to firms with a credit line and a rating of investment grade, and to firms with a credit line and a rating greater than A-. As can be expected, some coefficients become less significant as we move towards the smaller samples. However, some coefficients show persistence, in particular profitability, tangibility and dividend payer. Therefore, we can conclude that financial constraints are not the only drivers of the coefficients observed in column 2 .

One way to reconcile the findings of Table 3 is to rethink about the role of covenants. In many cases covenants impose requirements on profitability, collateral and allow for the payment of dividends only after the cash flow sweeps have been satisfied. Therefore, a possible explanation for the findings of column 2 is that firms need to meet the criteria imposed by the covenants attached to the credit line, in order to hold liquidity in the form of undrawn credit. In the next section we explore this issue from a different angle and look at the uses of credit lines.

\subsection{The Purposes of Credit Line Usage}

In this section we explore which expenditures are financed by credit line drawdowns. We do so from two angles: from an ex-ante perspective studying what the stated purpose of the line is on origination, and from an ex-post perspective examining the relationship between drawdowns and different types of expenditures.

Data on the stated purpose is obtained from LPC Dealscan and is illustrated in Figure 6. More than $80 \%$ of firms have General Purposes as one of their stated purposes, which 
suggests that the majority of credit lines does not carry very restrictive contractual terms with respect to the usage objectives. Still, around one in five lines of credit specify what the lines of credit can finance, and for this subset clearly cash holdings offer a more flexible source of liquidity.

In Table 4 we relate credit line drawdowns to several categories of expenditures, namely inventory increases, acquisitions, capital expenditures, and increases in account receivables. All categories are significantly related to decreases in undrawn credit and increases in drawn credit, and on average around 5-15\% of these expenditures, except for capital expenditures, are financed by credit line drawdowns. Capital expenditures do not seem to use lines of credit as a source of finance to such an extent, and on average less than $1 \%$ of that category uses funds arising from lines of credit.

\section{Accessing a credit line}

Table 5 provides a sample overview and a comparison of characteristics of firms with and without a credit line. Columns 1-2, and 3-4 respectively provide information for the subsamples of firms with and without a credit line.

The main picture that emerges from the table is that firms with a credit line are larger, more leveraged, more profitable, have fewer growth opportunities and more tangible assets, and are more likely to be rated and to pay dividends. More precisely, firms with a credit line are on average three times larger in size $(\$ 2.67 \mathrm{bn}$ vs. $\$ 0.85 \mathrm{bn})$ as measured by the book value of assets (CPI deflated in 2001 dollars), and have leverage of $23.6 \%$ versus $15.1 \%$ of firms without a credit line. This observation is consistent with the view that access to a credit line is a good measure of whether a firm is financially constrained (Sufi (2009)). According to this interpretation leverage in firms without a credit line is lower because raising external finance for these firms is costlier than for firms with a credit line. Also along these lines we observe that only $8.5 \%$ of firms without a credit line are rated compared to $34.7 \%$ of firms 
with a credit line.

To measure growth opportunities we employ the $\mathrm{M} / \mathrm{B}$ ratio, $\mathrm{R} \& \mathrm{D}$ expenditures, and acquisition activity. Firms with a credit line have a lower M/B ratio (1.575 vs. 2.308), a lower ratio of R\&D expenses over sales (a median of $0 \%$ vs. 11.8\%), and higher acquisition expenses (3\% vs. 2\%). ${ }^{6}$ The fact that firms with a credit line display lower R\&D but higher acquisition expenditures may suggest that these firms tend to grow externally via acquisitions rather than organically, as opposed to firms without access to a credit line. Profitability is measured by the ratio of cash flows to assets, which is positive $(6.3 \%)$ for firms with a credit line, and negative otherwise $(-9.9 \%)$. The information on profitability is supported by the data on dividend payment behavior. Firms with a credit line are often dividend payers $(36 \%)$, while this is not the case for non-credit line holders (10.7\%). These findings lend support to the claim in Sufi (2009) that firms that suffer from poor operating performance are unlikely to be able to obtain a credit line, and, should they already have one, are more likely to see it revoked.

To test formally for the differences between these two samples for each of the eleven variables analyzed above, we perform a t-test for unpaired data with unequal variances and a two-sample Wilcoxon rank-sum (Mann-Whitney) test. Both the parametric and the nonparametric tests show that the two samples are different along all of the eleven dimensions with a $1 \%$ significance level.

Finally, another dimension along which these two samples strongly differ is cash holdings. Firms with a credit line have a significantly lower cash to assets ratio (14.1\%) than firms without a credit line (40.5\%). This finding suggests that cash and credit lines are to some extent substitutes for the purpose of corporate liquidity management. It also reinforces the notion that access to a credit line could be an accurate measure of financial constraints as firms without a credit line tend to hoard high levels of cash, possibly to be able to have

\footnotetext{
${ }^{6}$ For $R \& D$ expenses over sales, we compare medians rather than means because the mean of this ratio for firms without a credit line is likely to be influenced by the extremely low values of sales. Specifically, there are 407 firm-years with sales below 1 million dollars in the sample of firms without a credit line.
} 
access to funds in the future when external finance may not be available for them. Adding more evidence in this direction, firms without a credit line have on average a negative ratio of net working capital to assets, which suggests that they might rely to a large extent on trade credit given that other sources of finance may not be available.

\subsection{Size}

As already noted, size appears strongly related to reliance on credit lines. Figure 2 illustrates how larger firms tend to have less liquidity than smaller firms. Across the entire sample (Panel A), we observe that liquidity amounts to $40 \%$ of assets for firms in the lowest size quintile. For these firms, the majority of liquidity comes as cash. In the highest size quintile liquidity amounts to less than $20 \%$ and is almost equally shared between cash and credit lines. When we look at the sample of firms with a credit line (Panel B), the importance of credit lines as a percentage of liquidity increases significantly. Cash is prevalent in the first two quartiles, and smaller than credit lines for the other quartiles. Liquidity is also smaller across all quartiles with respect to the entire sample.

Figure 8 illustrates the importance of credit lines as a percentage of firm assets. Panel A shows that across the entire sample approximately $30 \%$ of firms carry credit lines in the range (>) $0-10 \%$ of assets, $20 \%$ of firms have them in the range of $10 \%-20 \%$ of assets, and $10 \%$ of firms are in the range 20\%-30\%. Overall there are more firms with high cash ratios than firms with large credit lines (as a \% of assets). However, in Panel B we see that conditional on having a credit line, the ratio of the available credit over assets is significantly larger across the whole spectrum. Over $30 \%$ of firms carry credit lines that amount to $20 \%-30 \%$ of assets.

\subsection{Credit ratings}

Another dimension that is relevant for access to credit lines is whether a firm is rated or not. Among unrated firms, the percentage of firms with a credit line is $60.01 \%$, while in the 
sample of firms that are rated investment grade, the percentage of firms with a credit line is $93.26 \% .^{7}$ This staggering difference is also reflected in the relative reliance on credit lines and cash as a percentage of assets across the two samples as shown in Figure 9.

Table 6 displays the distribution of credit lines across ratings. A total of 6,038 firmyears are rated, while 16,975 are unrated. We consider a firm-year as rated if S\&P has assigned a rating for at least one month of the year. If there are different ratings for months of the same year we take the equal weighted average of these ratings to compute the yearly rating. Observing the first column, there is a striking difference in the presence of a credit line between firms with a rating equal to or above B- and firms with a rating below this threshold or without a rating. For the first group, the percentage of firms with a credit line ranges between $84 \%$ and $94 \%$, while for the second group the range is between $60 \%$ (unrated) and $68.3 \%(\mathrm{CCC}+$ or below). We take this as an indicator of a strong correlation between rating and access to credit lines. The causality can go both ways as on one hand rating agencies take into consideration whether a firm has access to a credit line in order to evaluate its liquidity position and credit rating, and on the other hand having a good rating by S\&P may make it more likely to be granted a credit line by a bank.

For firms with rating equal to or above $\mathrm{B}-$, the distribution of credit lines is non monotonic, reaching a maximum for firms with $\mathrm{BBB}+/-$. In particular, the highest rated firms in the sample (AAA) do not have the highest proportion of credit lines. Presumably, this does not happen because these firms are denied a credit line, but because they have very easy access to external capital, including commercial paper, and therefore do not need to hoard liquidity in any form. This small set of highly rated firms without a credit line also holds the lowest percentage of cash to assets (6.1\%) in the whole sample. The ratio of cash to assets is highest for unrated firms (17.2\%), which are also the group with the smallest average size ( $\$ 454.1$ million). This ratio is almost twice as much as that of any other subset of rated firms, for which cash to assets is in the range of 8-9\%. The ratio increases sharply

\footnotetext{
${ }^{7}$ Notice that this percentage does not account for firms that have a credit line as guarantee of commercial paper.
} 
for the group of firms without a rating or a credit line (42.3\%) which suggests that for these firms, who might be likely to face financing constraints, the precautionary motive to hoard cash is strongest.

Surprisingly, the AAA group of firms with a credit line also holds a relatively large percentage of cash to assets (14\%). This group is composed of only six firms, namely Automatic Data Processing, Exxon Mobil, GE, Johnson and Johnson, Pfizer and UPS. Compared to the average firm in the sample, these firms have larger cash flows to assets (8.6\%), negative net working capital $(-1.4 \%)$, and lower capex and R\&D expenditures (respectively $3.4 \%$ and $6.3 \%$ ). One possible interpretation is that these firms are cash generators with limited growth opportunities for which the potential dividend (Free Cash-Flow To Equity (FCFE)) is larger than the actual dividend paid to shareholders.

\subsection{Industry seasonality}

We then examine the possible role of seasonality of cash flows in determining whether firms are more likely to have a credit line. Table 7 illustrates the distribution of credit lines across industries. The first column reports the percentage of firms with a credit line and shows that there is significant variation across sectors. Construction, wholesale and retail trade have the highest percentage of firms with a credit line (respectively, 89.8\%, 84.8\%, and $83.6 \%$ ), while manufacturing and services have the lowest percentages (respectively, 65.3\% and $60.3 \%$ ). Conditional on having a credit line the differences in the percentage of credit lines over assets also varies significantly across sectors, with transportation, communication, electric gas and sanitary services $(10.5 \%)$ having the lowest percentage, and wholesale trade the highest $(16.2 \%)$. The sectors with the lowest proportion of firms with a credit line are also those for which cash represents the largest share of assets. The ratio of cash to assets for manufacturing and services is respectively $46.6 \%$ and $40.3 \%$, which is four time that of construction (11.3\%). This is the second piece of evidence of a negative relationship between cash and credit lines. 
In the last column we report the average industry volatility of cash flows, which is computed as the standard deviation of EBITDA over the fiscal year and then scaled by the book value of assets. This variable measures the within-year variation of cash flows and is higher for industries with a high level of seasonality. If credit lines are held for the purpose of smoothing the volatility of cash flows due to seasonality, then we should expect to observe a positive relationship between cash flow volatility and the percentage of firms with a credit line. Contrary to this prediction, an examination of Table 7 does not reveal a clear pattern in the relationship between these two variables. Therefore, this finding does not provide support to the seasonality explanation.

\subsection{Multivariate evidence on access to credit lines}

In this section we provide multivariate evidence on the factors that are predicted to affect the extensive margin of credit lines. In our main specification we conduct a Probit analysis in which the dependent variable is a dummy that indicates the presence of a credit line. Our main explanatory variables include profitability measured by the ratio of EBITDA over assets. We borrow this measure from Sufi (2009) which predicts that profitable firms use credit lines more intensely as they are less likely to violate the covenants imposed by the credit agreement.

We then look at size and rating as both are measures of a firm's degree of financial constraints. We expect both measures to be positively related to the use of credit lines, as large and rated firms are less financially constrained, and therefore banks are more willing to commit to offer them credit in the future.

We then look at systematic risk, following the prediction of Acharya, Almeida and Campello (2010) that firms with more systematic risk represent less attractive borrowers for banks. Following these authors we measure systematic risk using the market beta.

We measure seasonality by computing the standard deviation of cash flows within a given year and average it out at the industry three digit SIC code level. We expect to observe 
a positive relationship between seasonality and the use of credit lines.

Finally, as Yun (2009) suggests firms with better corporate governance are less likely to need credit lines to manage their liquidity, as they can employ cash without being exposed to managerial opportunism. We measure corporate governance by constructing an index that is obtained as the sum of the following three dummies: 1) dummy equal to one if the firm's CEO is not the chairman of the board (COB), 2) dummy equal to one if the firm has independent directors in the board, 3) dummy equal one if the size of the board is small.

Table 8 provides the results of our analysis and offers the first large sample evidence on the determinants of credit lines, encompassing all the explanations provided so far in the literature. In column 1 we provide a specification that contains all the six variables of interest. In column 2 we exclude governance as this variable is tolling in terms of observations. In columns 3-5 we control for other firm characteristics as well as exchange and year fixed effects. Robust standard errors clustered at the firm level. In all columns with the exception of column 5, all right hand side variables are contemporaneous with respect to the dependent variable. In column 5 the right hand side variables are lagged by one year. This ensures their predetermination when the choice of having a credit line is made, and it acts as a robustness check.

Table 8 confirms that profitability, size and rating are positively related to the use of credit lines. The relationship with profitability appears to be strong across all columns. The relationship with size and rating takes the right sign but is not always significant once we control for other firm characteristics. We confirm the predictions of a negative relationship between the quality of corporate governance and the use of credit lines, as predicted by Yun (2009), as well as the prediction that high beta firms are less likely to have a credit line. The relationship between the use of credit lines and our measure of seasonality appears to go in the opposite direction from what predicted, as firms with higher seasonality are less likely to have a credit line.

In columns 6 and 7 we examine the use of credit lines from a different angle and look 
at the cash ratio, which we define as the ratio of cash over the sum of cash and credit lines. As expected all the coefficients switch sign, thus providing broad support to the findings obtained in the previous columns.

\section{The cross-sensitivity of cash and credit lines}

The previous sections may suggest that cash and credit lines are substitutes to some extent, as lines of credit seem to be used for almost all the purposes that cash holdings can be used for, and also that there is a mean reversion of the three measures of liquidity towards an equilibrium level. In this section we question to what extent cash and credit lines react to the reciprocal excessive amounts.

First, univariate evidence illustrated in Table 9 shows that as we increase cash, undrawn credit tends to diminish, although the reverse happens to total liquidity. Therefore, there seems to be some degree of substitutability between these two liquidity instruments.

In Table 10 we find that if cash is above target, undrawn credit does not adjust while cash instead increases if undrawn credit is above target, and this second effect seems to be due to drawing down of lines of credit. ${ }^{8}$ So overall, there is some sensitivity which suggests substitutability, but it is clearly one directional. This suggests that there are high costs to holding cash, and low costs to holding lines of credit, so when a firm is able to decrease its cash holdings because it has liquidity available under lines of credit, it will do so, but excess cash does not lead firms to cancel their lines of credit.

\section{Conclusions}

We examine credit lines as part of corporate liquidity together with cash holdings and show that there is an optimum liquidity level towards which firms revert over time. The optimum

\footnotetext{
${ }^{8}$ In Table A5 in the appendix we provide different specifications of the target levels for cash and undrawn credit lines. Results of Table 10 are robust to these alternative specifications.
} 
level of liquidity is driven by the determinants of cash holdings and credit lines. We show that the latter two variables are affected by very different factors. While cash holdings can be justified in terms of precautionary reasons, credit lines appear to be lower for exactly those firms that need more precautionary liquidity. Both access to credit lines and the amount of credit lines as a percentage of assets are typically associated with better firms, which are less in need of precautionary liquidity.

By examining the characteristics of credit lines we show that most of these agreements specify a specific purpose for which the line has been issued, which limits the uses of the credit lines. We show that the uses of credit lines are indeed primarily related to the stated purposes, and in particular to working capital, capital expenditures, acquisitions and refinancing. In addition to this, credit line agreements carry covenants that impose restrictive conditions on key financial variables such as leverage, interest coverage ratios, tangibility and profitability. This evidence provides an explanation to why firms with poorer prospects are less likely to hold a credit line, and if they have one it represents a smaller percentage of their assets. 


\section{References}

[1] Acharya, Viral V., Heitor Almeida and Murillo Campello, 2010. "Aggregate Risk and the Choice between Cash and credit lines," NBER Working Papers 16122.

[2] Almeida, Heitor, Murillo Campello and Dirk Hackbarth, 2011. "Liquidity Mergers," NBER Working Papers 16724.

[3] Almeida, H., M. Campello, and M. Weisbach (2004). "The Cash Flow Sensitivity of Cash," The Journal of Finance, 59(4), 1777-1804

[4] Bates, Thomas W., Kathleen M. Kahle and René M. Stulz, 2009. "Why Do U.S. Firms Hold So Much More Cash than They Used To?," Journal of Finance, vol. 64(5).

[5] Baumol, W. J., 1952, The transactions demand for cash: An inventory theoretic approach, Quarterly Journal of Economics 66, 545-556.

[6] Boot, A., A.V. Thakor, and G.F. Udell. (1987). "Competition, risk neutrality and loan commitments," Journal of Banking \& Finance, 15, 605-632.

[7] Campello, Murillo, Erasmo Giambona, John R. Graham and Campbell R. Harvey. "Liquidity Management and Corporate Investment During a Financial Crisis," forthcoming Review of Financial Studies.

[8] DeMarzo, Peter M. and Sannikov, Yuliy, (2006), Optimal Security Design and Dynamic Capital Structure in a Continuous-Time Agency Model, Journal of Finance, 61, 6, 26812724 .

[9] Fama, Eugene F. and French, Kenneth R., 1993. "Common risk factors in the returns on stocks and bonds," Journal of Financial Economics, vol. 33(1), pages 3-56, February.

[10] Fama, Eugene F. and French, Kenneth R., 2002, "Testing trade-off and pecking order predictions about dividends and debt," Review of Financial Studies 15, 1-33. 
[11] Flannery, Mark J. and Rangan, Kasturi P., 2006. "Partial adjustment toward target capital structures," Journal of Financial Economics, vol. 79(3).

[12] Gertler, Mark and Simon Gilchrist, 1993, "Monetary policy, business cycles, and the behavior of small manufacturing firms", The Quarterly Journal of Economics 109(2), 309-40.

[13] Heckman, James J, 1979. "Sample Selection Bias as a Specification Error," Econometrica, vol. 47(1), pages 153-61, January.

[14] Holmstrom, B., and J. Tirole. (1998). "Private and Public Supply of Liquidity," Journal of Political Economy, 106(1), 1-40

[15] Ivashina, V., and D.S. Scharfstein. (2009). "Bank Lending During the Financial Crisis of 2008,". EFA 2009 Bergen Meetings Paper.

[16] Jiménez, G. , J.A. López and J. Saurina. (2008). "Empirical analysis of corporate credit lines", Review of Financial Studies, 22(12), 5069-5098

[17] Iyer, Rajkamal, Samuel Lopes, José-Luis Peydró, and Antoinette Schoar, (2010), "Interbank liquidity crunch and the firm credit crunch: Evidence from the 2007-2009 crisis", unpublished, MIT.

[18] Kahle, Kathleen M. and René M. Stulz. "Financial Policies and the Financial Crisis: How Important Was the Systemic Credit Contraction for Industrial Corporations?" NBER, and ECGI Dice Center WP 2010-13

[19] Lemmon, Michael L., Michael R. Roberts and Jaime F. Zender, 2008. "Back to the Beginning: Persistence and the Cross-Section of Corporate Capital Structure," Journal of Finance, vol. 63(4). 
[20] Lins, K.V., H. Servaes, and P. Tufano. "What Drives Corporate Liquidity? International Evidence from Survey Data on Strategic Cash and credit lines," Journal of Financial Economics, Vol 98 (2010) 160-176

[21] Opler, Tim, Pinkowitz, Lee, Stulz, Rene and Williamson, Rohan, 1999. "The determinants and implications of corporate cash holdings," Journal of Financial Economics, vol. 52(1).

[22] Strahan, Philip E. (1999) "Borrower Risk and the Price and Nonprice Terms of Bank Loans" Banking Studies Function October 1999

[23] Sufi, Amir. (2009). "Bank credit lines in Corporate Finance: An Empirical Analysis", Review of Financial Studies, 22(3), 1057-1088

[24] Yun H. (2009). "The Choice of Corporate Liquidity and Corporate Governance," Review of Financial Studies, 22(4), 1447-1475 


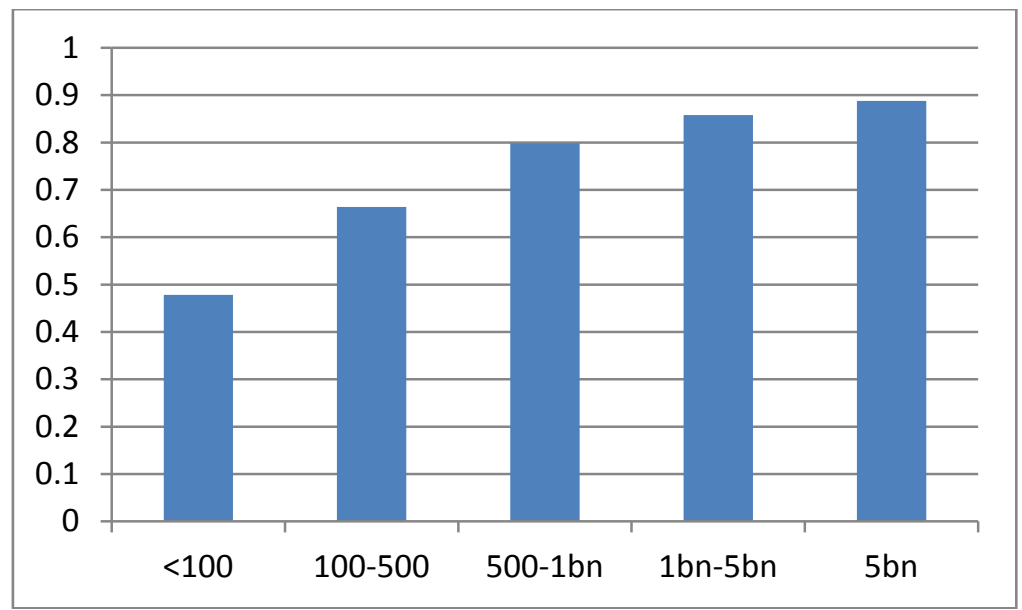

Figure 1: The use of credit lines by size groups

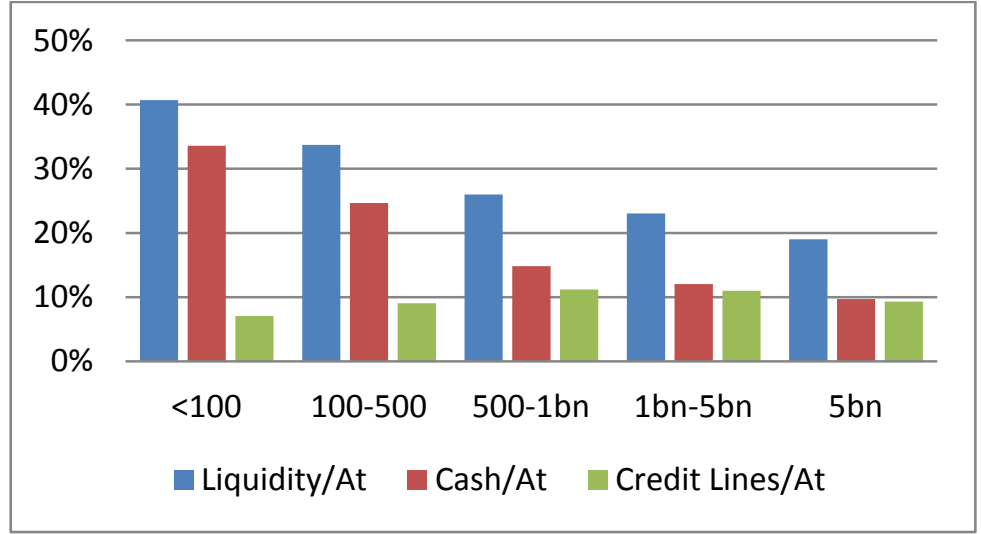

Panel A: Entire Sample

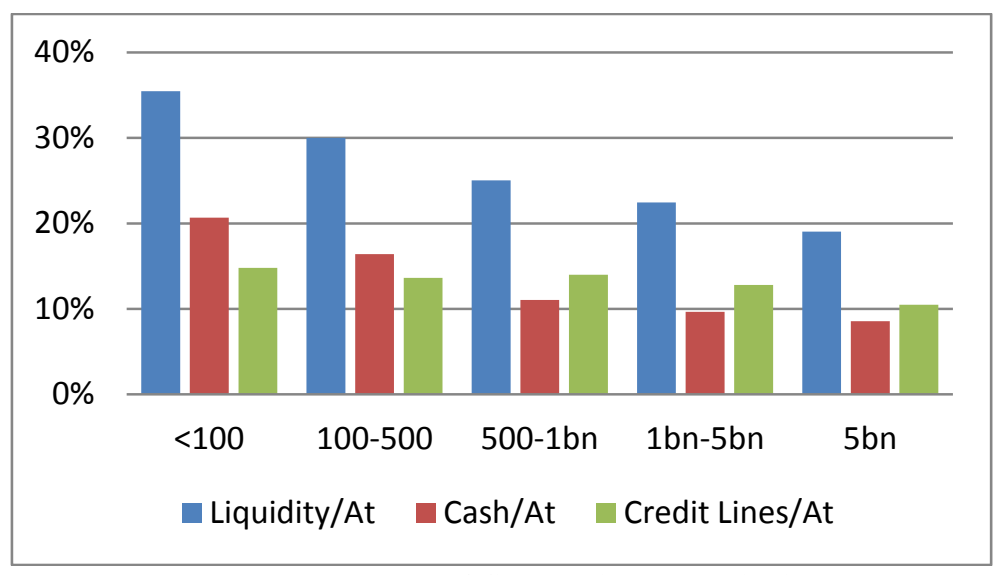

Panel B: Sample of firms with a credit line

Figure 2: Size and the composition of liquidity 


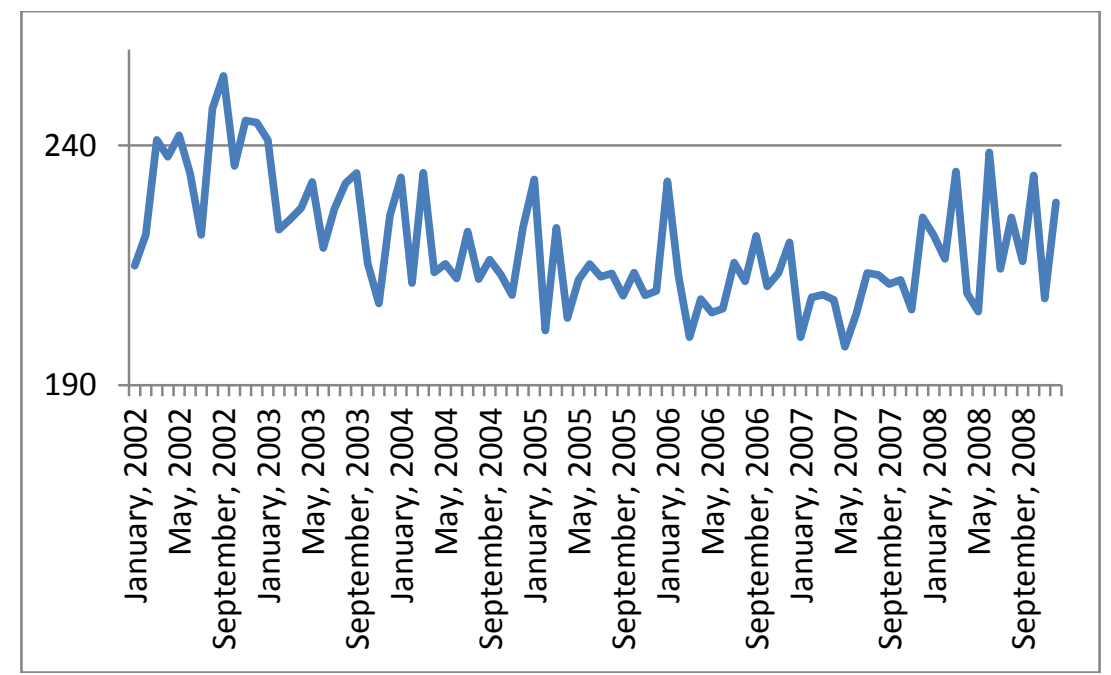

Figure 3: Spreads on drawdowns of credit lines

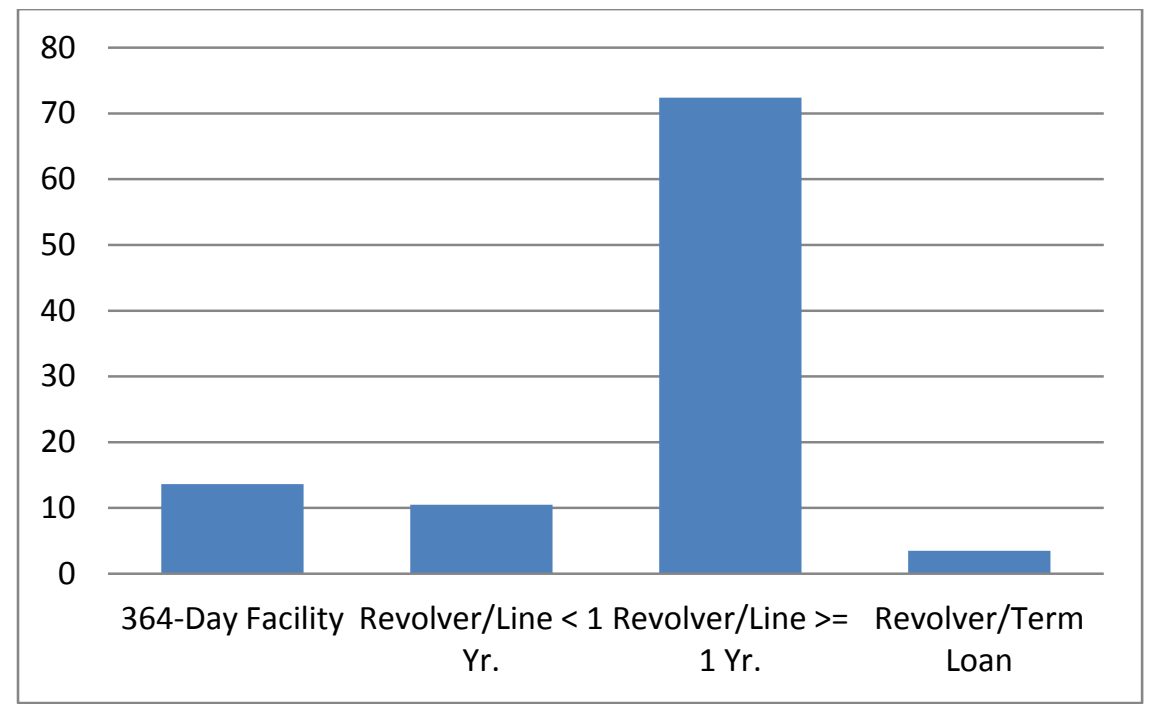

Figure 4: Types of Credit Lines 


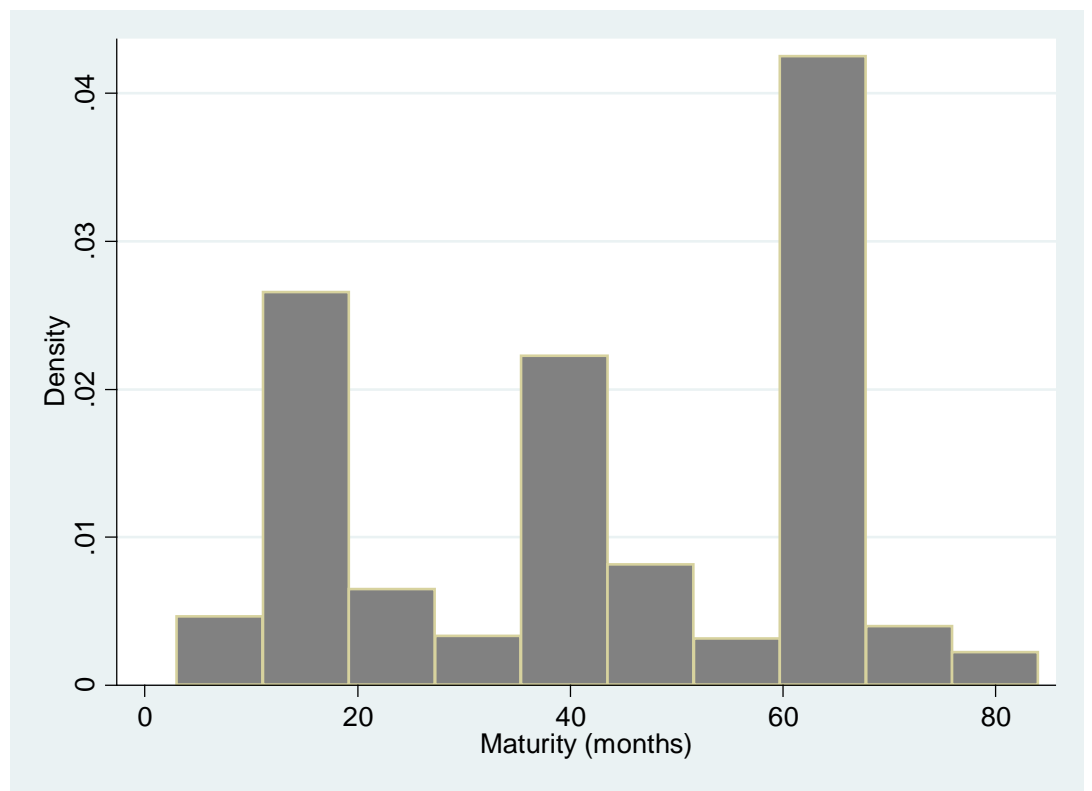

Figure 5: Maturities of credit lines

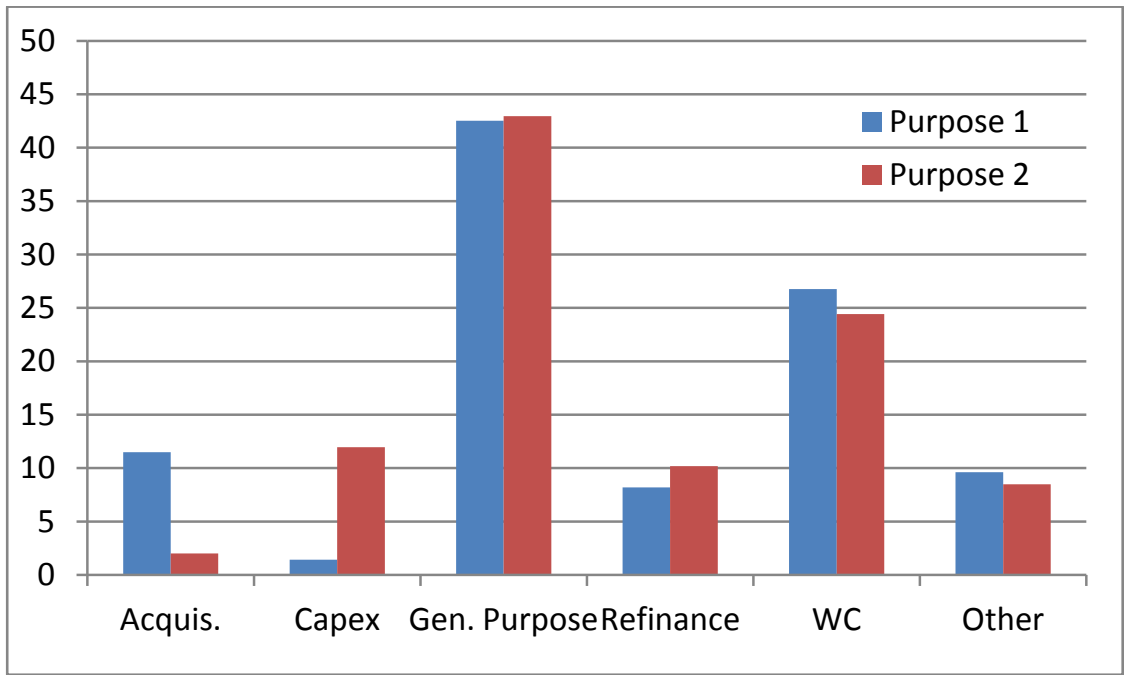

Figure 6: Stated purposes of credit lines 


\section{Table 1}

Covenants on Credit Lines

This table reports the frequency of the covenants observed on the sample of 13.115 credit lines issued to the firms covered by Compustat and Capital IQ over the period 2002-2008. Data is obtained from LPC Dealscan.

\begin{tabular}{lc}
\hline Covenant Type & Frequency \\
\hline Leverage and Interest Coverage Limitations & $51.22 \%$ \\
\hline Max Debt/EBITDA & $29.90 \%$ \\
Max Debt/Equity & $0.27 \%$ \\
Max. Debt to Tangible Net Worth & $3.44 \%$ \\
Max. Leverage ratio & $11.38 \%$ \\
Max. Senior Debt to EBITDA & $5.56 \%$ \\
Max. Senior Leverage & $0.60 \%$ \\
Min. Debt Service Coverage & $2.87 \%$ \\
Min. Interest Coverage & $21.91 \%$ \\
Min. Fixed Charge Coverage & $20.18 \%$ \\
Liquidity Requirements & $18.23 \%$ \\
\hline Min. Quick Ratio & $1.05 \%$ \\
Min. Current Ratio & $3.23 \%$ \\
Max Capex & $14.73 \%$ \\
Collateral Requirements & $50.93 \%$ \\
\hline Net Worth & $9.60 \%$ \\
Collateral release & $27.72 \%$ \\
Tangible Net Worth & $8.22 \%$ \\
Profitability Requirements & $6.33 \%$ \\
\hline Min. EBITDA & $6.32 \%$ \\
Percentage of net income & $0.02 \%$ \\
Sweeps & $21.38 \%$ \\
\hline Debt issuance sweep & $14.20 \%$ \\
Asset sales sweep & $19.10 \%$ \\
Equity issuance sweep & $12.41 \%$ \\
Excess Cash Flow sweep & $7.94 \%$ \\
Insurance proceeds sweep & $12.92 \%$ \\
\hline & \\
\hline
\end{tabular}




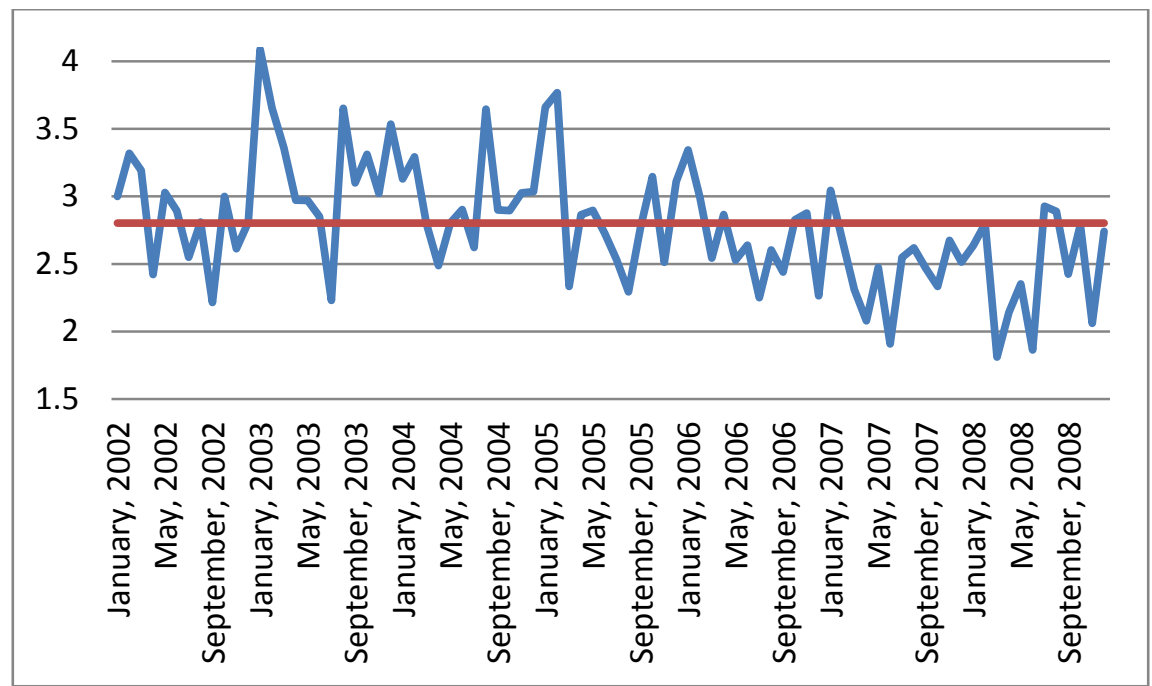

Figure 7: The evolution of covenants over time 
Table 2

Dynamic Test of the Trade-off Theory of Liquidity

This table presents OLS regression results to test the trade-off theory of liquidity. The dependent variable is alternatively the year on year change in liquidity (measured as the sum of cash and (undrawn) credit lines), change in cash, and change in (undrawn) credit lines. The liquidity (respectively cash, and credit lines) mean target adjustment is computed as the difference in liquidity (resp. cash, credit lines) and the average liquidity in the sample (resp. cash, credit lines). Definitions of the variables are provided in Table A1. All specifications include year, rating and exchange fixed effects. Rating fixed effects are based on 22 rating dummies and the unrated dummy. Robust standard errors clustered at the firm level are reported in parentheses. All regressions include a (non-reported) constant, year, rating , and exchange fixed effects. ${ }^{* *},{ }^{* *}$, and $*$ denote statistical significance at the $1 \%, 5 \%$, and $10 \%$ levels, respectively.

\begin{tabular}{|c|c|c|c|c|c|}
\hline & $\begin{array}{c}\text { (1) } \\
\text { Change in } \\
\text { Liquidity }\end{array}$ & $\begin{array}{c}(2) \\
\text { Change in } \\
\text { Cash }\end{array}$ & $\begin{array}{l}\text { (3) } \\
\text { Change in Credit } \\
\text { Lines }\end{array}$ & $\begin{array}{c}\text { (4) } \\
\text { Change in } \\
\text { Cash }\end{array}$ & $\begin{array}{l}\text { (5) } \\
\text { Change in Credit } \\
\text { Lines }\end{array}$ \\
\hline Liquidity Mean Target Adj. & $\begin{array}{c}-0.357 * * * \\
(0.008)\end{array}$ & $\begin{array}{c}-0.208 * * * \\
(0.007)\end{array}$ & $\begin{array}{c}-0.149 * * * \\
(0.006)\end{array}$ & & \\
\hline Cash Mean Target Adj. & & & & $\begin{array}{c}-0.267 * * * \\
(0.008)\end{array}$ & \\
\hline CL Mean Target Adj. & & & & & $\begin{array}{c}-0.416^{* * *} \\
(0.012)\end{array}$ \\
\hline Size & $\begin{array}{c}-0.007 * * * \\
(0.001)\end{array}$ & $\begin{array}{c}-0.005^{* * *} \\
(0.001)\end{array}$ & $\begin{array}{c}-0.002^{* * *} \\
(0.000)\end{array}$ & $\begin{array}{c}-0.004 * * * \\
(0.001)\end{array}$ & $\begin{array}{c}-0.004^{* * *} \\
(0.001)\end{array}$ \\
\hline Book Leverage & $\begin{array}{c}-0.077 * * * \\
(0.007)\end{array}$ & $\begin{array}{c}-0.035^{* * *} \\
(0.005)\end{array}$ & $\begin{array}{c}-0.042^{* * *} \\
(0.004)\end{array}$ & $\begin{array}{c}-0.061 * * * \\
(0.006)\end{array}$ & $\begin{array}{c}0.011^{* * *} \\
(0.003)\end{array}$ \\
\hline $\mathrm{M} / \mathrm{B}$ & $\begin{array}{c}0.008^{* * *} \\
(0.001)\end{array}$ & $\begin{array}{c}0.006^{* * *} \\
(0.001)\end{array}$ & $\begin{array}{c}0.003 * * * \\
(0.000)\end{array}$ & $\begin{array}{c}0.007 * * * \\
(0.001)\end{array}$ & $\begin{array}{l}-0.001 \\
(0.000)\end{array}$ \\
\hline Tangibility & $\begin{array}{c}-0.120 * * * \\
(0.009)\end{array}$ & $\begin{array}{c}-0.091^{* * *} \\
(0.007)\end{array}$ & $\begin{array}{c}-0.030 * * * \\
(0.005)\end{array}$ & $\begin{array}{c}-0.107 * * * \\
(0.007)\end{array}$ & $\begin{array}{c}0.014^{* * * *} \\
(0.005)\end{array}$ \\
\hline Profitability & $\begin{array}{c}0.029 * * * \\
(0.008)\end{array}$ & $\begin{array}{c}0.046 * * * \\
(0.007)\end{array}$ & $\begin{array}{c}-0.017^{* * * *} \\
(0.004)\end{array}$ & $\begin{array}{c}0.027 * * * \\
(0.007)\end{array}$ & $\begin{array}{c}0.018^{* * *} \\
(0.004)\end{array}$ \\
\hline NWC/Assets & $\begin{array}{c}-0.124^{* * *} \\
(0.009)\end{array}$ & $\begin{array}{c}-0.101^{* * *} \\
(0.007)\end{array}$ & $\begin{array}{c}-0.024^{* * *} \\
(0.005)\end{array}$ & $\begin{array}{c}-0.147 * * * \\
(0.008)\end{array}$ & $\begin{array}{c}0.065^{* * *} \\
(0.005)\end{array}$ \\
\hline Capex/Assets & $\begin{array}{c}-0.230 * * * \\
(0.024)\end{array}$ & $\begin{array}{c}-0.235 * * * \\
(0.021)\end{array}$ & $\begin{array}{c}0.005 \\
(0.016)\end{array}$ & $\begin{array}{c}-0.256^{* * *} \\
(0.020)\end{array}$ & $\begin{array}{c}0.019 \\
(0.016)\end{array}$ \\
\hline R\&D/Sales & $\begin{array}{c}0.002^{* * *} \\
(0.000)\end{array}$ & $\begin{array}{c}0.001^{* * *} \\
(0.000)\end{array}$ & $\begin{array}{c}0.000 * * * \\
(0.000)\end{array}$ & $\begin{array}{c}0.002^{* * *} \\
(0.000)\end{array}$ & $\begin{array}{l}-0.000 * \\
(0.000)\end{array}$ \\
\hline Dividend Payer & $\begin{array}{c}0.005^{* *} \\
(0.002)\end{array}$ & $\begin{array}{l}0.003^{*} \\
(0.002)\end{array}$ & $\begin{array}{c}0.001 \\
(0.001)\end{array}$ & $\begin{array}{c}-0.004^{* *} \\
(0.002)\end{array}$ & $\begin{array}{c}0.011^{* * *} \\
(0.002)\end{array}$ \\
\hline Acquisition Activity & $\begin{array}{c}-0.496^{* * *} \\
(0.016)\end{array}$ & $\begin{array}{c}-0.438^{* * *} \\
(0.016)\end{array}$ & $\begin{array}{c}-0.059 * * * \\
(0.012)\end{array}$ & $\begin{array}{c}-0.454^{* * *} \\
(0.015)\end{array}$ & $\begin{array}{c}-0.045^{* * *} \\
(0.010)\end{array}$ \\
\hline $\begin{array}{l}\text { Observations } \\
\text { R-sauared }\end{array}$ & $\begin{array}{c}17,499 \\
0,296\end{array}$ & $\begin{array}{c}17,499 \\
0,221\end{array}$ & $\begin{array}{c}17,499 \\
0,096\end{array}$ & $\begin{array}{c}17,499 \\
0,268\end{array}$ & $\begin{array}{c}17,500 \\
0,233\end{array}$ \\
\hline
\end{tabular}


Table 3

Predicting Firm Liquidity Levels

This table presents OLS regression results to predict the liquidity levels respectively for cash holdings, (undrawn) credit lines, and liquidity. Definitions of the variables are provided in Table A1. All specifications include year, rating and exchange fixed effects. Rating fixed effects are based on 22 rating dummies and the unrated dummy. In column 4 we compute net assets as book value of assets minus cash holdings. In column 5 the sample includes only firms with a credit line. In column 6 the sample includes only firms with a credit line and with an investment grade rating. In column 7 the sample includes only firms with a credit line and a rating greater than A-. Robust standard errors clustered at the firm level are reported in parentheses. All regressions include a (non-reported) constant, year, rating , and exchange fixed effects. ${ }^{* * *},{ }^{* *}$, and ${ }^{*}$ denote statistical significance at the $1 \%, 5 \%$, and $10 \%$ levels, respectively.

\begin{tabular}{|c|c|c|c|c|c|c|c|}
\hline & \multicolumn{4}{|c|}{ Entire Sample } & \multirow{2}{*}{$\begin{array}{c}\text { Firms with a } \\
\text { Credit Line } \\
(5)\end{array}$} & \multirow{2}{*}{$\begin{array}{l}\text { With a CL and } \\
\text { Invest. Grade } \\
(6)\end{array}$} & \multirow{2}{*}{$\begin{array}{c}\text { With a CL and } \\
\text { Rating > A- } \\
\text { (7) }\end{array}$} \\
\hline & (1) & (2) & (3) & (4) & & & \\
\hline & Cash/Assets & Credit Lines/At & Liquidity & Credit Lines/Net At & Credit Lines/At & Credit Lines/At & Credit Lines/At \\
\hline \multirow[t]{2}{*}{ Profitability } & $-0.200 * * *$ & $0.083^{* * *}$ & $-0.117 * * *$ & $0.102 * * *$ & $0.096 * * *$ & $0.254 * * *$ & $0.296 * *$ \\
\hline & $(0.019)$ & $(0.008)$ & $(0.017)$ & $(0.010)$ & $(0.016)$ & $(0.073)$ & $(0.129)$ \\
\hline \multirow[t]{2}{*}{ Size } & $-0.025 * * *$ & 0.000 & $-0.025^{* * *}$ & -0.002 & $-0.008 * * *$ & $-0.024 * * *$ & $-0.031 * * *$ \\
\hline & $(0.002)$ & $(0.001)$ & $(0.002)$ & $(0.001)$ & $(0.001)$ & $(0.003)$ & $(0.005)$ \\
\hline \multirow[t]{2}{*}{ Industry Sigma } & $0.053 * * *$ & $-0.036 * * *$ & 0.017 & $-0.040 * * *$ & $-0.024 * * *$ & -0.002 & 0.312 \\
\hline & $(0.014)$ & $(0.007)$ & $(0.011)$ & $(0.008)$ & $(0.009)$ & $(0.026)$ & $(0.226)$ \\
\hline \multirow[t]{2}{*}{ Beta } & $0.012 * * *$ & $-0.004 * * *$ & $0.008 * * *$ & $-0.004 * * *$ & $-0.003 * * *$ & -0.002 & 0.006 \\
\hline & $(0.001)$ & $(0.001)$ & $(0.001)$ & $(0.001)$ & $(0.001)$ & $(0.003)$ & $(0.007)$ \\
\hline \multirow[t]{2}{*}{ Rated } & $0.027 * * *$ & $-0.007^{*}$ & $0.020 * * *$ & $-0.009 *$ & -0.001 & & \\
\hline & $(0.006)$ & $(0.004)$ & $(0.006)$ & $(0.005)$ & $(0.004)$ & & \\
\hline \multirow[t]{2}{*}{ Book Leverage } & $-0.206 * * *$ & $0.015 * *$ & $-0.191 * * *$ & 0.000 & $-0.015^{*}$ & 0.047 & 0.053 \\
\hline & $(0.015)$ & $(0.006)$ & $(0.014)$ & $(0.007)$ & $(0.008)$ & $(0.035)$ & $(0.059)$ \\
\hline \multirow[t]{2}{*}{$\mathrm{M} / \mathrm{B}$} & $0.032 * * *$ & $-0.003^{* * *}$ & $0.029 * * *$ & -0.001 & -0.002 & -0.004 & -0.010 \\
\hline & $(0.002)$ & $(0.001)$ & $(0.002)$ & $(0.001)$ & $(0.001)$ & $(0.006)$ & $(0.008)$ \\
\hline \multirow[t]{2}{*}{ Tangibility } & $-0.237 * * *$ & 0.003 & $-0.233^{* * *}$ & $-0.014 *$ & $-0.030 * * *$ & $-0.131 * * *$ & $-0.136 * * *$ \\
\hline & $(0.010)$ & $(0.007)$ & $(0.010)$ & $(0.007)$ & $(0.008)$ & $(0.018)$ & $(0.038)$ \\
\hline \multirow[t]{2}{*}{ Dividend Payer } & $-0.022 * * *$ & $0.032 * * *$ & $0.010 * *$ & $0.033^{* * *}$ & $0.027 * * *$ & $0.041^{* * *}$ & $0.077 * * *$ \\
\hline & $(0.005)$ & $(0.004)$ & $(0.005)$ & $(0.004)$ & $(0.004)$ & $(0.009)$ & $(0.029)$ \\
\hline Observations & 17,548 & 17,550 & 17,548 & 17,548 & 12,446 & 2,189 & 881 \\
\hline R-squared & 0.490 & 0.112 & 0.385 & 0.075 & 0.042 & 0.159 & 0.191 \\
\hline
\end{tabular}




\section{Table 4}

What Credit Lines are Used For

This table presents OLS regression results to explain the change in credit lines. The dependent variable is the change in undrawn credit lines as a percentage of assets in column 1-5, while it is the change in drawn credit lines in column 6. Definitions of the variables are provided in Table A1. All specifications include year, rating and exchange fixed effects. Rating fixed effects are based on 22 rating dummies and the unrated dummy. Robust standard errors clustered at the firm level are reported in parentheses. $* * *, * *$, and $*$ denote statistical significance at the $1 \%, 5 \%$, and $10 \%$ levels, respectively.

\begin{tabular}{|c|c|c|c|c|c|c|}
\hline & \multicolumn{5}{|c|}{ Change in Undrawn CL } & $\begin{array}{c}(6) \\
\text { Change } \\
\text { in Drawn CL }\end{array}$ \\
\hline Inventories Change & $\begin{array}{c}-0.174 * * * \\
(0.035)\end{array}$ & & & & $\begin{array}{c}-0.159 * * * \\
(0.036)\end{array}$ & $\begin{array}{c}0.140 * * * \\
(0.022)\end{array}$ \\
\hline Acquisitions & & $\begin{array}{c}-0.088^{* * *} \\
(0.012)\end{array}$ & & & $\begin{array}{c}-0.089 * * * \\
(0.012)\end{array}$ & $\begin{array}{c}0.096^{* * *} \\
(0.009)\end{array}$ \\
\hline Capex & & & $\begin{array}{c}-0.004^{* *} \\
(0.002)\end{array}$ & & $\begin{array}{c}-0.007 * * * \\
(0.002)\end{array}$ & $\begin{array}{c}0.010^{* * * *} \\
(0.002)\end{array}$ \\
\hline Account Rec. Change & & & & $\begin{array}{c}-0.120 * * * \\
(0.026)\end{array}$ & $\begin{array}{c}-0.105^{* * *} \\
(0.027)\end{array}$ & $\begin{array}{l}0.032^{*} \\
(0.017)\end{array}$ \\
\hline Size & $\begin{array}{c}-0.001^{* * *} \\
(0.000)\end{array}$ & $\begin{array}{c}-0.001^{* *} \\
(0.000)\end{array}$ & $\begin{array}{c}-0.001^{* * *} \\
(0.000)\end{array}$ & $\begin{array}{c}-0.001 * * * \\
(0.000)\end{array}$ & $\begin{array}{c}-0.001^{* *} \\
(0.000)\end{array}$ & $\begin{array}{c}0.000 \\
(0.000)\end{array}$ \\
\hline Book Leverage & $\begin{array}{c}-0.015^{* * *} \\
(0.003)\end{array}$ & $\begin{array}{c}-0.011^{* * *} \\
(0.003)\end{array}$ & $\begin{array}{c}-0.015^{* * *} \\
(0.003)\end{array}$ & $\begin{array}{c}-0.014 * * * \\
(0.003)\end{array}$ & $\begin{array}{c}-0.011^{* * *} \\
(0.003)\end{array}$ & $\begin{array}{c}0.021^{* * *} \\
(0.003)\end{array}$ \\
\hline $\mathrm{M} / \mathrm{B}$ & $\begin{array}{c}0.000 \\
(0.000)\end{array}$ & $\begin{array}{l}-0.000 \\
(0.000)\end{array}$ & $\begin{array}{l}-0.000 \\
(0.000)\end{array}$ & $\begin{array}{c}0.000 \\
(0.000)\end{array}$ & $\begin{array}{c}0.000 \\
(0.000)\end{array}$ & $\begin{array}{l}-0.000 \\
(0.000)\end{array}$ \\
\hline Tangibility & $\begin{array}{c}0.013^{* * *} \\
(0.003)\end{array}$ & $\begin{array}{c}0.009 * * * \\
(0.003)\end{array}$ & $\begin{array}{c}0.013^{* * *} \\
(0.003)\end{array}$ & $\begin{array}{c}0.011^{* * *} \\
(0.003)\end{array}$ & $\begin{array}{c}0.008^{* * *} \\
(0.003)\end{array}$ & $\begin{array}{c}0.004 \\
(0.003)\end{array}$ \\
\hline $\mathrm{CF} /$ Assets & $\begin{array}{c}0.002 \\
(0.003)\end{array}$ & $\begin{array}{c}0.001 \\
(0.003)\end{array}$ & $\begin{array}{l}-0.000 \\
(0.003)\end{array}$ & $\begin{array}{c}0.003 \\
(0.003)\end{array}$ & $\begin{array}{l}0.006^{*} \\
(0.003)\end{array}$ & $\begin{array}{c}-0.013^{* * *} \\
(0.003)\end{array}$ \\
\hline R\&D/Sales & $\begin{array}{c}-0.000^{* *} \\
(0.000)\end{array}$ & $\begin{array}{c}-0.000^{* *} \\
(0.000)\end{array}$ & $\begin{array}{l}-0.000^{*} \\
(0.000)\end{array}$ & $\begin{array}{c}-0.000 * * \\
(0.000)\end{array}$ & $\begin{array}{c}-0.000^{* *} \\
(0.000)\end{array}$ & $\begin{array}{l}-0.000^{*} \\
(0.000)\end{array}$ \\
\hline Div.Payer & $\begin{array}{l}-0.000 \\
(0.001)\end{array}$ & $\begin{array}{l}-0.000 \\
(0.001)\end{array}$ & $\begin{array}{l}-0.000 \\
(0.001)\end{array}$ & $\begin{array}{l}-0.000 \\
(0.001)\end{array}$ & $\begin{array}{l}-0.001 \\
(0.001)\end{array}$ & $\begin{array}{c}0.004^{* * *} \\
(0.001)\end{array}$ \\
\hline $\begin{array}{l}\text { Observations } \\
\text { R-squared }\end{array}$ & $\begin{array}{c}17,848 \\
0.012\end{array}$ & $\begin{array}{c}17,848 \\
0.015\end{array}$ & $\begin{array}{c}17,848 \\
0.010\end{array}$ & $\begin{array}{c}17,848 \\
0.012\end{array}$ & $\begin{array}{c}17,848 \\
0.017\end{array}$ & $\begin{array}{c}17,091 \\
0.047\end{array}$ \\
\hline
\end{tabular}


Table 5

Comparison of Firms with and without a Credit Line

This table provides summary statistics respectively for the sample of firms with a credit line, and the sample of firms without a credit line. The reference sample consists of non-utilities (excluding SIC codes 4900-4949) and nonfinancials (excluding SIC codes 6000-6999) U.S. firms covered by both Capital IQ and Compustat from 2002 to 2008. We have removed firm- years with 1) negative revenues, and 2) negative or missing assets. After the above filtering, there are 23,013 firm-year observations involving 4,248 unique firms in the sample. Table A1 provides a full description of the variables listed below. All variables are winsorized at the $0.5 \%$ in both tails of the distribution. Assets are expressed in millions of 2001 dollars deflated by the consumer price index. The last two columns test for differences between samples with and without undrawn credit using the unequal t-test and the two-sample Wilcoxon rank-sum (Mann-Whitney) test.

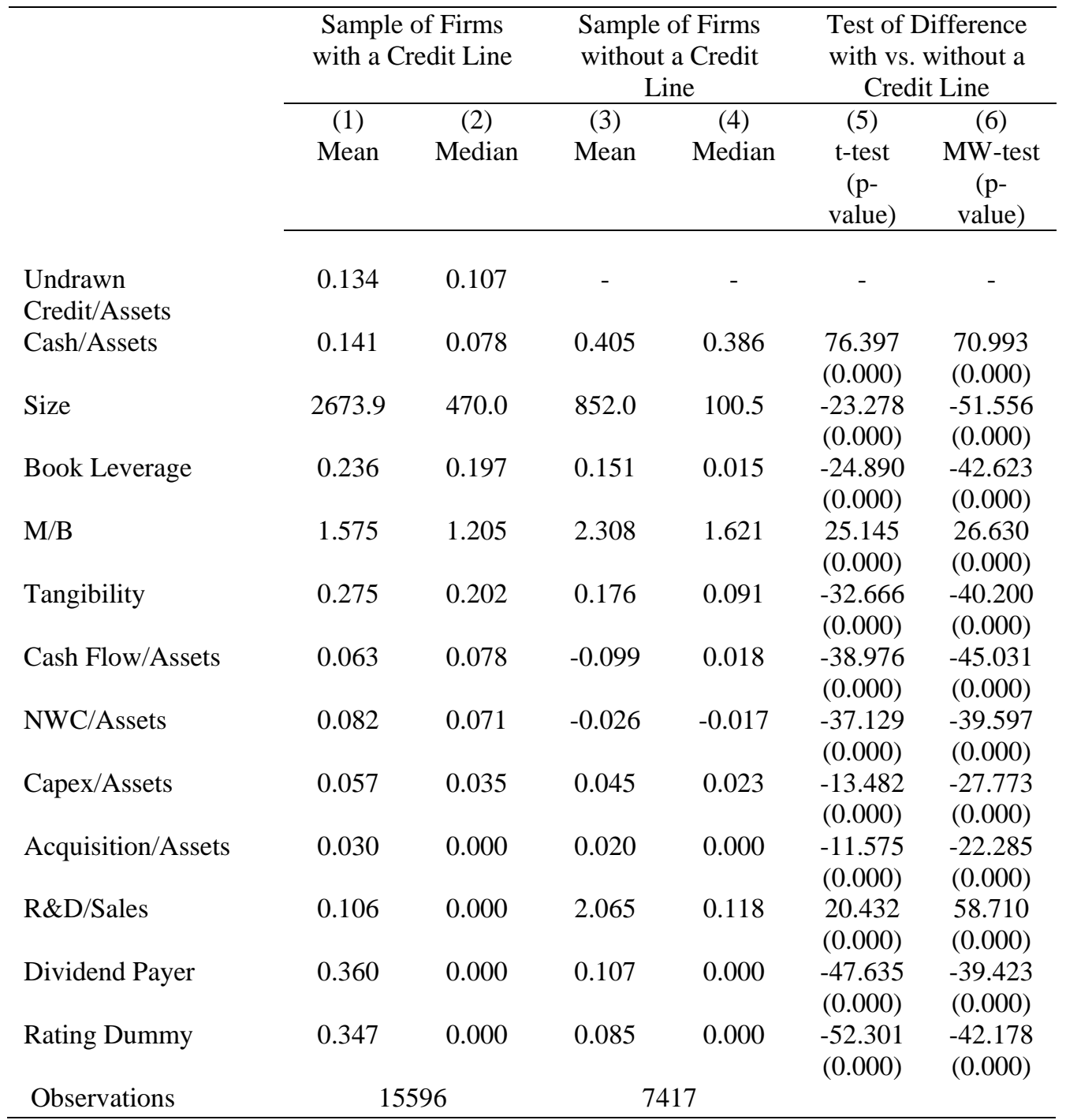




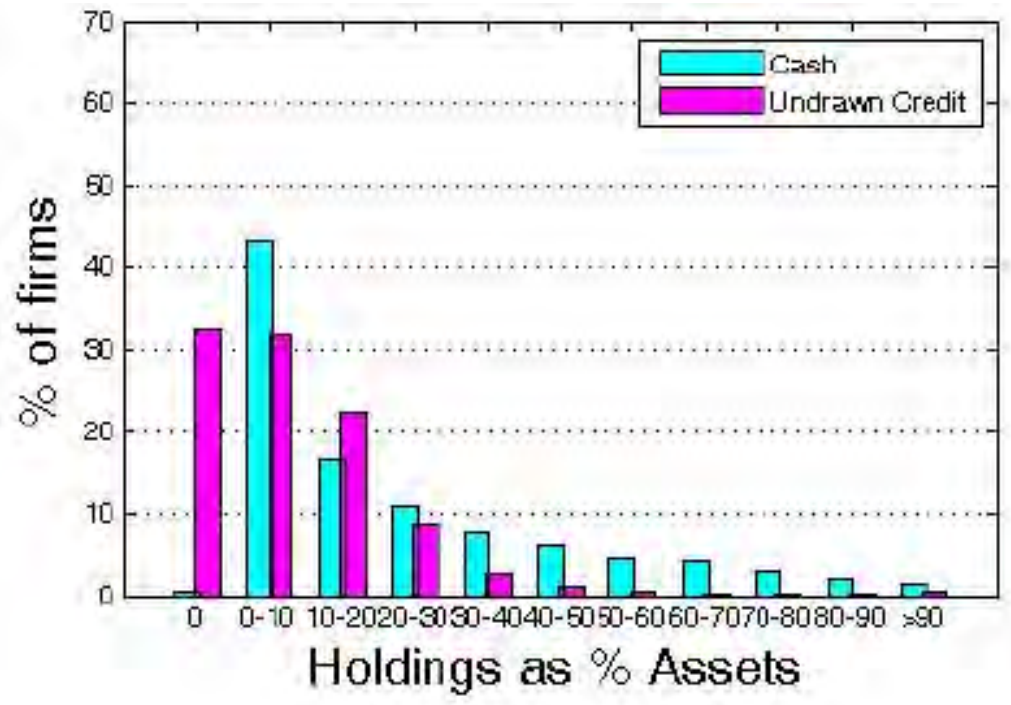

Panel A: All firms

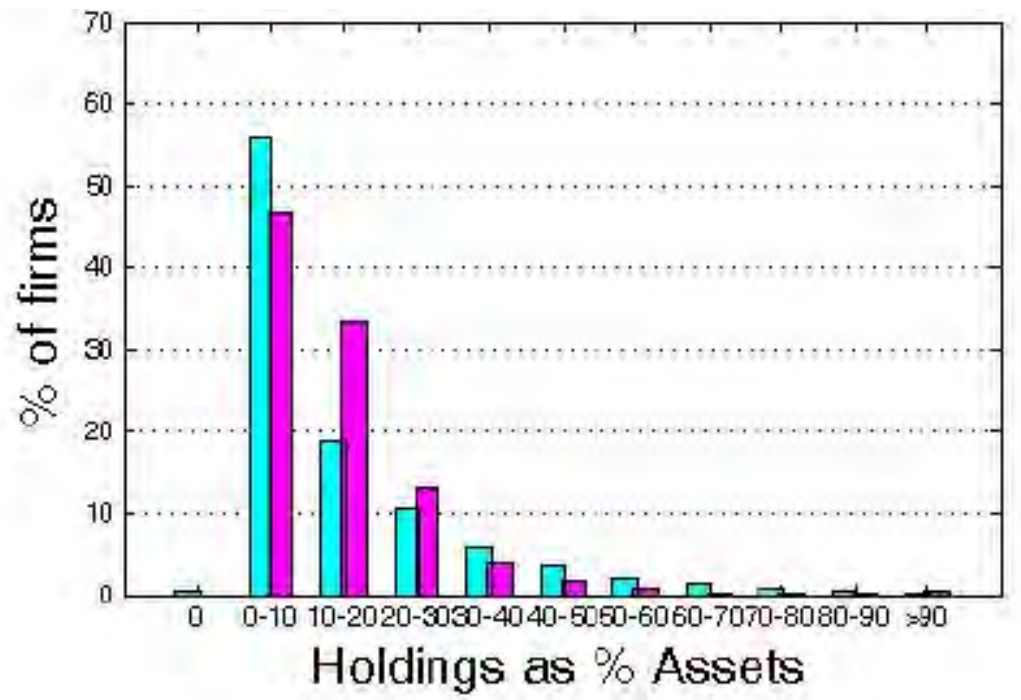

Panel B: Firms with a credit line

Figure 8: Cash and Credit Lines as a percentage of book value of assets 


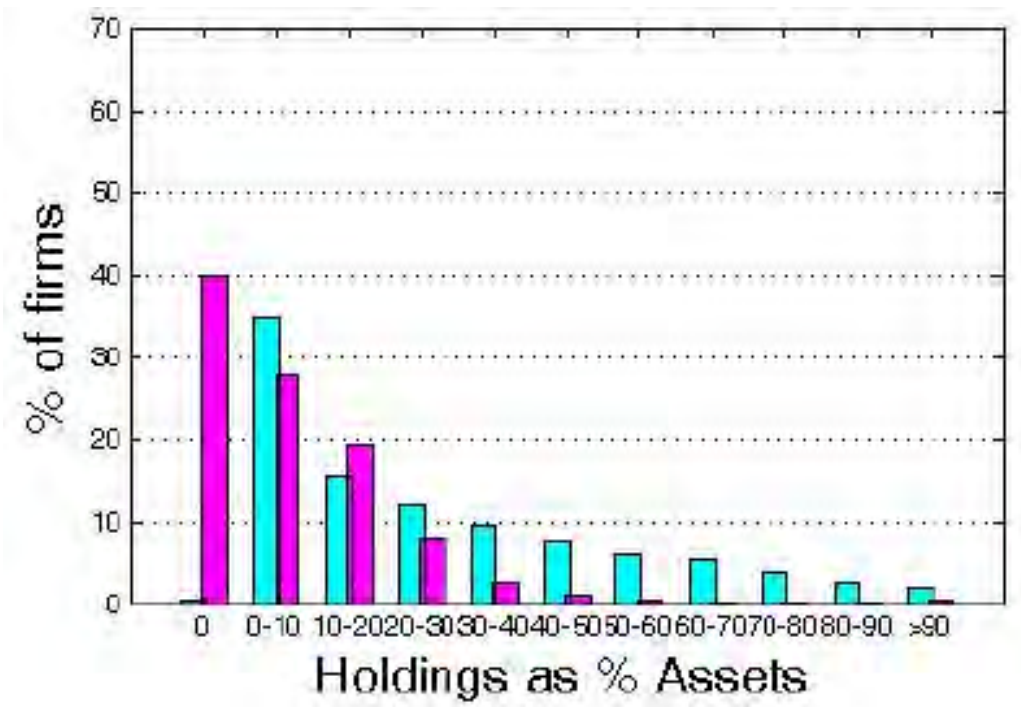

Panel A: Unrated Firms

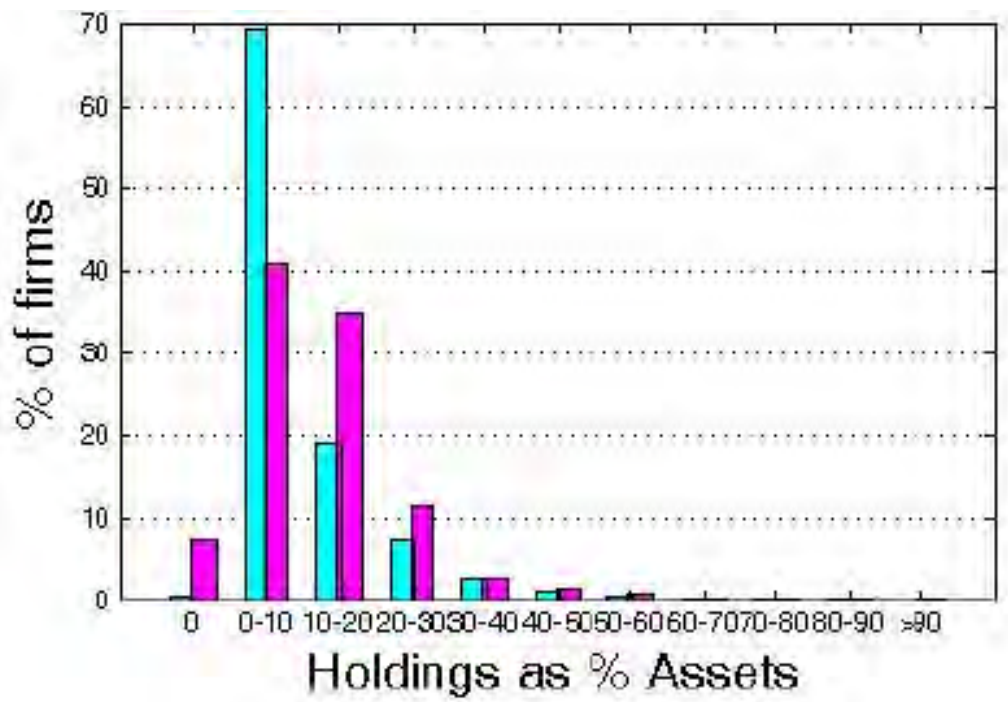

Panel B: Investment Grade Firms

Figure 9: The distribution of cash and credit lines across unrated firms and investment grade firms 


\section{Table 6}

Financial constraints and access to Credit Lines

This table illustrates the patterns of credit lines across different industries and S\&P ratings. The columns respectively contain 1) the percentage of firms with a credit line, 2) the percentage of credit lines over assets conditional on having a credit line, 3) the percentage of cash over assets conditional on having a credit line, 4) the percentage of cash over assets for firms without a credit line, 5) size (for the whole sample), 6) observation in each category. Data on ratings ranging from AAA to D are from Compustat (280).

\begin{tabular}{|c|c|c|c|c|c|c|}
\hline & $\begin{array}{l}\% \text { of Firms } \\
\text { with CL }\end{array}$ & $\begin{array}{c}\text { Undrawn } \\
\text { Credit Lines } \\
\text { / At (with CL) }\end{array}$ & $\begin{array}{l}\text { Cash /Assets } \\
\text { (with CL) }\end{array}$ & $\begin{array}{l}\text { Cash /Assets } \\
\text { (without CL) }\end{array}$ & Size & Obs. \\
\hline & $\begin{array}{c}\text { Mean } \\
\text { Median }\end{array}$ & $\begin{array}{l}\text { Mean } \\
\text { Median }\end{array}$ & $\begin{array}{l}\text { Mean } \\
\text { Median }\end{array}$ & $\begin{array}{c}\text { Mean } \\
\text { Median }\end{array}$ & $\begin{array}{c}\text { Mean } \\
\text { Median }\end{array}$ & \\
\hline AAA & 0.840 & $\begin{array}{l}0.169 \\
0.070\end{array}$ & $\begin{array}{l}0.140 \\
0.139\end{array}$ & $\begin{array}{l}0.061 \\
0.054\end{array}$ & $\begin{array}{l}51445.9 \\
64215.8\end{array}$ & 50 \\
\hline $\mathrm{AA}+/-$ & 0.926 & $\begin{array}{l}0.106 \\
0.082\end{array}$ & $\begin{array}{l}0.099 \\
0.078\end{array}$ & $\begin{array}{l}0.218 \\
0.145\end{array}$ & $\begin{array}{l}25592.1 \\
18228.8\end{array}$ & 121 \\
\hline $\mathrm{A}+/-$ & 0.926 & $\begin{array}{l}0.145 \\
0.117\end{array}$ & $\begin{array}{l}0.093 \\
0.062\end{array}$ & $\begin{array}{l}0.108 \\
0.062\end{array}$ & $\begin{array}{c}14825.1 \\
8157.0\end{array}$ & 807 \\
\hline $\mathrm{BBB}+/-$ & 0.940 & $\begin{array}{l}0.143 \\
0.121\end{array}$ & $\begin{array}{l}0.078 \\
0.050\end{array}$ & $\begin{array}{l}0.118 \\
0.062\end{array}$ & $\begin{array}{l}8382.9 \\
3800.1\end{array}$ & 1516 \\
\hline $\mathrm{BB}+/-$ & 0.915 & $\begin{array}{l}0.121 \\
0.101\end{array}$ & $\begin{array}{l}0.078 \\
0.045\end{array}$ & $\begin{array}{l}0.187 \\
0.149\end{array}$ & $\begin{array}{l}3267.1 \\
1779.7\end{array}$ & 1887 \\
\hline $\mathrm{B}+/-$ & 0.853 & $\begin{array}{l}0.110 \\
0.089\end{array}$ & $\begin{array}{l}0.083 \\
0.055\end{array}$ & $\begin{array}{l}0.301 \\
0.223\end{array}$ & $\begin{array}{c}2367.1 \\
883.7\end{array}$ & 1310 \\
\hline CCC + or less & 0.683 & $\begin{array}{l}0.118 \\
0.086\end{array}$ & $\begin{array}{l}0.094 \\
0.051\end{array}$ & $\begin{array}{l}0.253 \\
0.185\end{array}$ & $\begin{array}{c}2031.9 \\
665.3\end{array}$ & 347 \\
\hline Unrated & 0.600 & $\begin{array}{l}0.137 \\
0.109\end{array}$ & $\begin{array}{l}0.172 \\
0.106\end{array}$ & $\begin{array}{l}0.423 \\
0.408\end{array}$ & $\begin{array}{l}454.1 \\
139.2\end{array}$ & 16975 \\
\hline
\end{tabular}




\section{Table 7}

\section{Seasonality and use of credit lines}

This table illustrates the patterns of undrawn credit across different industries and S\&P ratings. Table A1 provides a full description of the variables listed below. The columns respectively contain 1) the percentage of firms with a credit line, 2) the percentage of undrawn credit over assets conditional on having a credit line, 3) the percentage of cash over assets conditional on having a credit line, 4) the percentage of cash over assets for firms without a credit line, 5) size (for the whole sample), 6) observation in each category. Industry classification are based on two-digit SIC codes.

\begin{tabular}{|c|c|c|c|c|c|}
\hline & $\begin{array}{l}\text { \% of Firms } \\
\text { with CL }\end{array}$ & $\begin{array}{l}\text { Cash / } \\
\text { Assets }\end{array}$ & $\begin{array}{c}\text { Undrawn } \\
\text { Credit Lines/ At }\end{array}$ & Size & $\begin{array}{c}\text { Cash Flow } \\
\text { Volatility }\end{array}$ \\
\hline & Mean & $\begin{array}{l}\text { Mean } \\
\text { Median }\end{array}$ & $\begin{array}{l}\text { Mean } \\
\text { Median }\end{array}$ & $\begin{array}{l}\text { Mean } \\
\text { Median }\end{array}$ & $\begin{array}{c}\text { Mean } \\
\text { Median }\end{array}$ \\
\hline Agriculture et al. (1-9) & 0.765 & 0.116 & 0.104 & $\begin{array}{c}1567.6 \\
3487\end{array}$ & 0.025 \\
\hline Construction (15-17) & 0.898 & $\begin{array}{l}0.121 \\
0.094\end{array}$ & $\begin{array}{l}0.135 \\
0.108\end{array}$ & $\begin{array}{c}2212.9 \\
968.5\end{array}$ & $\begin{array}{l}0.022 \\
0.015\end{array}$ \\
\hline Manufacturing (20-39) & 0.653 & $\begin{array}{l}0.262 \\
0.167\end{array}$ & $\begin{array}{l}0.090 \\
0.059\end{array}$ & $\begin{array}{c}2081.9 \\
224.0\end{array}$ & $\begin{array}{l}0.023 \\
0.012\end{array}$ \\
\hline Mining (10-14) & 0.731 & $\begin{array}{l}0.091 \\
0.037\end{array}$ & $\begin{array}{l}0.095 \\
0.070\end{array}$ & $\begin{array}{c}2064.1 \\
503.9\end{array}$ & $\begin{array}{l}0.056 \\
0.020\end{array}$ \\
\hline Retail Trade (52-59) & 0.836 & $\begin{array}{l}0.127 \\
0.073\end{array}$ & $\begin{array}{l}0.117 \\
0.097\end{array}$ & $\begin{array}{c}2265.0 \\
444.2\end{array}$ & $\begin{array}{l}0.022 \\
0.014\end{array}$ \\
\hline Services (70-89) & 0.603 & $\begin{array}{l}0.273 \\
0.206\end{array}$ & $\begin{array}{l}0.076 \\
0.035\end{array}$ & $\begin{array}{c}1065.5 \\
187.3\end{array}$ & $\begin{array}{l}0.020 \\
0.010\end{array}$ \\
\hline Transp et al. (40-49) & 0.769 & $\begin{array}{l}0.124 \\
0.063\end{array}$ & $\begin{array}{l}0.081 \\
0.055\end{array}$ & $\begin{array}{c}5567.5 \\
827.6\end{array}$ & $\begin{array}{l}0.012 \\
0.006\end{array}$ \\
\hline Whole. Trade (50-51) & 0.848 & $\begin{array}{l}0.093 \\
0.042\end{array}$ & $\begin{array}{l}0.137 \\
0.116\end{array}$ & $\begin{array}{c}1290.1 \\
480.8\end{array}$ & $\begin{array}{l}0.014 \\
0.008\end{array}$ \\
\hline
\end{tabular}




\section{Table 8}

\section{What Determines the Presence of a Credit Line}

Probit specifications for the demand for credit lines. The sample consists of non-utilities (excluding SIC codes 49004949) and non-financials (excluding SIC codes 6000-6999) U.S. firms covered by both Capital IQ and Compustat from 2002 to 2008 for a total of 23,013 firm-years. We have removed firm-years with 1) negative revenues, and 2) negative or missing assets. The dependent variables in the three columns is a dummy for the presence of a credit line. The first two columns are identical except for the inclusion of fixed effects. In the third column the regressors are all lagged by one period. Rating fixed effects are based on 22 rating dummies and the unrated dummy. The cash ratio is defined as the ratio of cash over cash plus credit lines. Robust standard errors clustered at the firm level are reported in parentheses. In column 5 coefficients are lagged by one year. ***, **, and * denote statistical significance at the $1 \%, 5 \%$, and $10 \%$ levels, respectively.

\begin{tabular}{|c|c|c|c|c|c|c|c|}
\hline & (1) & (2) & (3) & (4) & (5) & (6) & (7) \\
\hline & \multicolumn{5}{|c|}{ Credit Line (Dummy) } & \multicolumn{2}{|c|}{ Cash Ratio } \\
\hline & Probit & Probit & Probit & Probit & Probit & OLS & OLS \\
\hline Profitability & $\begin{array}{c}2.703^{* * *} \\
(0.466)\end{array}$ & $\begin{array}{c}1.272 * * * \\
(0.154)\end{array}$ & $\begin{array}{c}3.503 * * * \\
(0.581)\end{array}$ & $\begin{array}{c}1.120^{* * *} \\
(0.161)\end{array}$ & $\begin{array}{c}\text { Lagged } \\
1.288^{* * *} \\
(0.201)\end{array}$ & $\begin{array}{c}-0.403^{* * *} \\
(0.087)\end{array}$ & $\begin{array}{c}-0.274 * * * \\
(0.022)\end{array}$ \\
\hline Size & $\begin{array}{c}0.146 * * * \\
(0.043)\end{array}$ & $\begin{array}{c}0.205 * * * \\
(0.015)\end{array}$ & $\begin{array}{c}0.035 \\
(0.046)\end{array}$ & $\begin{array}{c}0.149 * * * \\
(0.017)\end{array}$ & $\begin{array}{c}0.148 * * * \\
(0.020)\end{array}$ & $\begin{array}{c}0.000 \\
(0.007)\end{array}$ & $\begin{array}{c}-0.034 * * * \\
(0.003)\end{array}$ \\
\hline Industry CF Volatility & $\begin{array}{l}-0.102 \\
(0.122)\end{array}$ & $\begin{array}{l}-0.150 \\
(0.094)\end{array}$ & $\begin{array}{l}-0.108 \\
(0.117)\end{array}$ & $\begin{array}{l}-0.167^{*} \\
(0.089)\end{array}$ & $\begin{array}{c}-0.194 * * \\
(0.088)\end{array}$ & $\begin{array}{l}0.066^{*} \\
(0.034)\end{array}$ & $\begin{array}{c}0.068^{* * *} \\
(0.022)\end{array}$ \\
\hline Beta & $\begin{array}{c}-0.144 * * * \\
(0.034)\end{array}$ & $\begin{array}{c}-0.081^{* * * *} \\
(0.010)\end{array}$ & $\begin{array}{c}-0.116 * * * \\
(0.037)\end{array}$ & $\begin{array}{c}-0.052 * * * \\
(0.011)\end{array}$ & $\begin{array}{c}-0.061^{* * * *} \\
(0.011)\end{array}$ & $\begin{array}{c}0.047 * * * \\
(0.006)\end{array}$ & $\begin{array}{c}0.034 * * * \\
(0.002)\end{array}$ \\
\hline Rated & $\begin{array}{c}0.282 * * * \\
(0.102)\end{array}$ & $\begin{array}{c}0.254 * * * \\
(0.055)\end{array}$ & $\begin{array}{c}0.153 \\
(0.112)\end{array}$ & $\begin{array}{l}-0.010 \\
(0.062)\end{array}$ & $\begin{array}{l}-0.045 \\
(0.073)\end{array}$ & $\begin{array}{c}-0.073 * * * \\
(0.021)\end{array}$ & $\begin{array}{c}-0.104 * * * \\
(0.014)\end{array}$ \\
\hline Governance Index & $\begin{array}{l}-0.093^{*} \\
(0.050)\end{array}$ & & $\begin{array}{l}-0.054 \\
(0.055)\end{array}$ & & & $\begin{array}{c}0.032 * * * \\
(0.010)\end{array}$ & \\
\hline Book Leverage & & & $\begin{array}{c}0.240 \\
(0.306)\end{array}$ & $\begin{array}{c}0.596 * * * \\
(0.116)\end{array}$ & $\begin{array}{c}0.640^{* * *} \\
(0.136)\end{array}$ & & \\
\hline $\mathrm{M} / \mathrm{B}$ & & & $\begin{array}{c}-0.247^{* * *} \\
(0.044)\end{array}$ & $\begin{array}{c}-0.097 * * * \\
(0.018)\end{array}$ & $\begin{array}{c}-0.105^{* * * *} \\
(0.019)\end{array}$ & & \\
\hline Tangibility & & & $\begin{array}{c}0.136 \\
(0.249)\end{array}$ & $\begin{array}{c}0.655^{* * * *} \\
(0.104)\end{array}$ & $\begin{array}{c}0.669 * * * \\
(0.125)\end{array}$ & & \\
\hline Dividend Payer & & & $\begin{array}{c}0.382 * * * \\
(0.108)\end{array}$ & $\begin{array}{c}0.307 * * * \\
(0.051)\end{array}$ & $\begin{array}{c}0.360 * * * \\
(0.061)\end{array}$ & & \\
\hline Constant & $\begin{array}{c}0.165 \\
(0.313)\end{array}$ & $\begin{array}{c}-0.610^{* * *} \\
(0.075)\end{array}$ & $\begin{array}{c}0.874 * * \\
(0.397)\end{array}$ & $\begin{array}{c}-0.701^{* * *} \\
(0.127)\end{array}$ & $\begin{array}{l}-0.154 \\
(0.145)\end{array}$ & $\begin{array}{c}0.431 * * * \\
(0.057)\end{array}$ & $\begin{array}{c}0.804^{* * *} \\
(0.016)\end{array}$ \\
\hline Exchange FE & No & No & Yes & Yes & Yes & No & No \\
\hline Year FE & No & No & Yes & Yes & Yes & No & No \\
\hline $\begin{array}{l}\text { Observations } \\
\text { R-squared }\end{array}$ & 5,087 & 17,581 & 5,070 & 17,549 & 14,095 & $\begin{array}{l}5,085 \\
0.073\end{array}$ & $\begin{array}{c}17,573 \\
0.195\end{array}$ \\
\hline Pseudo R-squared & 0.128 & 0.186 & 0.208 & 0.246 & 0.258 & . & . \\
\hline
\end{tabular}




\section{Table 9}

Sorting firms by Cash Holdings Quartiles

This table displays a univariate comparison of firm characteristics across different quartiles of cash holdings. The tstatistic in the last column is for a difference of means test from the first to the fourth quartile.

\begin{tabular}{|c|c|c|c|c|c|c|c|c|c|}
\hline & \multicolumn{2}{|c|}{ First Quartile } & \multicolumn{2}{|c|}{ Second Quartile } & \multicolumn{2}{|c|}{ Third Quartile } & \multicolumn{2}{|c|}{ Fourth Quartile } & \multirow{2}{*}{$\begin{array}{c}\text { t-statistics } \\
\text { (p-value) }\end{array}$} \\
\hline & Mean & Median & Mean & Median & Mean & Median & Mean & Median & \\
\hline Cash/Assets & 0.016 & 0.015 & 0.077 & 0.074 & 0.225 & 0.217 & 0.587 & 0.557 & $\begin{array}{c}-252.411 \\
(0.000)\end{array}$ \\
\hline Und. Credit/At & 0.129 & 0.106 & 0.118 & 0.094 & 0.086 & 0.055 & 0.030 & 0.000 & $\begin{array}{l}55.623 \\
(0.000)\end{array}$ \\
\hline Liquidity & 0.144 & 0.121 & 0.195 & 0.169 & 0.312 & 0.295 & 0.617 & 0.596 & $\begin{array}{c}-174.087 \\
(0.000)\end{array}$ \\
\hline Size & 2733.9 & 572.2 & 3295.2 & 564.8 & 1852.4 & 265.8 & 464.9 & 93.4 & $\begin{array}{l}21.365 \\
(0.000) \\
\end{array}$ \\
\hline
\end{tabular}




\section{Table 10}

The Cross-sensitivity of cash and credit lines

This table presents OLS regression results to explain the relationship between cash and credit lines. The dependent variable is the change in (undrawn) credit lines as a percentage of assets in column 1, the change in cash as a percentage of assets for column 2, and the change in drawn credit lines as a percentage of assets in column 3. Definitions of the variables are provided in Table A1. Robust standard errors clustered at the firm level are reported in parentheses. All regressions include a (non-reported) constant, year, rating, and exchange fixed effects. ***, **, and * denote statistical significance at the $1 \%, 5 \%$, and $10 \%$ levels, respectively.

\begin{tabular}{|c|c|c|c|}
\hline & $\begin{array}{l}(1) \\
\text { Change in } \\
\text { Undrawn CL }\end{array}$ & $\begin{array}{c}(2) \\
\text { Change in } \\
\text { Cash }\end{array}$ & $\begin{array}{c}(3) \\
\text { Change } \\
\text { in Drawn CL }\end{array}$ \\
\hline Cash Mean Target Adj. & $\begin{array}{l}-0.004 \\
(0.003)\end{array}$ & & \\
\hline CL Mean Target Adj. & & $\begin{array}{c}0.088^{* * *} \\
(0.008)\end{array}$ & $\begin{array}{c}0.037 * * * \\
(0.006)\end{array}$ \\
\hline Size & $\begin{array}{l}-0.001 \\
(0.000)\end{array}$ & $\begin{array}{c}-0.003^{* * *} \\
(0.001)\end{array}$ & $\begin{array}{c}0.001^{* *} \\
(0.000)\end{array}$ \\
\hline Book Leverage & $\begin{array}{c}-0.011^{* * *} \\
(0.003)\end{array}$ & $\begin{array}{c}0.005 \\
(0.004)\end{array}$ & $\begin{array}{c}0.020^{* * *} \\
(0.003)\end{array}$ \\
\hline $\mathrm{M} / \mathrm{B}$ & $\begin{array}{c}0.000 \\
(0.000)\end{array}$ & $\begin{array}{c}0.002^{* * *} \\
(0.001)\end{array}$ & $\begin{array}{l}-0.000 \\
(0.000)\end{array}$ \\
\hline Tangibility & $\begin{array}{c}0.016 * * * \\
(0.004)\end{array}$ & $\begin{array}{c}-0.023 * * * \\
(0.006)\end{array}$ & $\begin{array}{c}-0.010^{* *} \\
(0.004)\end{array}$ \\
\hline CF/Assets & $\begin{array}{l}-0.004 \\
(0.004)\end{array}$ & $\begin{array}{c}0.061^{* * *} \\
(0.007)\end{array}$ & $\begin{array}{c}-0.012 * * * \\
(0.003)\end{array}$ \\
\hline NWC/Assets & $\begin{array}{c}0.015^{* * *} \\
(0.004)\end{array}$ & $\begin{array}{c}-0.054 * * * \\
(0.006)\end{array}$ & $\begin{array}{c}-0.010^{* * *} \\
(0.003)\end{array}$ \\
\hline Capex/Assets & $\begin{array}{c}-0.043 * * * \\
(0.017)\end{array}$ & $\begin{array}{c}-0.317^{* * *} \\
(0.021)\end{array}$ & $\begin{array}{c}0.089 * * * \\
(0.016)\end{array}$ \\
\hline R\&D/Sales & $\begin{array}{l}-0.000 * \\
(0.000)\end{array}$ & $\begin{array}{c}0.000 \\
(0.000)\end{array}$ & $\begin{array}{c}-0.000 * * \\
(0.000)\end{array}$ \\
\hline Div.Payer & $\begin{array}{l}-0.001 \\
(0.001)\end{array}$ & $\begin{array}{l}-0.003 * \\
(0.002)\end{array}$ & $\begin{array}{c}0.003^{* * *} \\
(0.001)\end{array}$ \\
\hline Acqu. Activity & $\begin{array}{c}-0.090^{* * *} \\
(0.012)\end{array}$ & $\begin{array}{c}-0.491^{* * *} \\
(0.018)\end{array}$ & $\begin{array}{c}0.094^{* * *} \\
(0.009)\end{array}$ \\
\hline $\begin{array}{l}\text { Observations } \\
\text { R-squared }\end{array}$ & $\begin{array}{c}17,499 \\
0,016\end{array}$ & $\begin{array}{c}17,499 \\
0,128\end{array}$ & $\begin{array}{c}16,761 \\
0,054\end{array}$ \\
\hline
\end{tabular}




\begin{tabular}{ll} 
Variable & Construction \\
& \\
\hline Acquisition Activity / Assets & Acquisitions (129) / Total Assets (6) \\
Book Leverage & Total Debt / Total Assets (6) \\
BV Equity & Total Assets (6) - Total Liabilities (181) - Deferred Taxes and Investment Tax \\
& Credit (35) - Preferred Stock \\
Cash Flow /Assets & Operating Income Before Depreciation (13) - Interest Expenses (15) - Income \\
& Taxes (16) - Dividends (21) \\
Cash/Assets & Cash and Investments (1) / Total Assets (6) \\
CF Volatility & Quarters Scaled by Total Assets (6) \\
& Spread on U.S. corporate bond yields between Moody's AAA and BAA, averages of \\
Credit Spread & seasoned issues (from Datastream) \\
& A dummy variable that takes the value of one if common stock dividends (21) are \\
Dividend Payer & positive, and zero otherwise \\
& Logarithm of Book Value of Total Assets (6) \\
Firm Size & Sum of dummy for CEO not COB, plus dummy for the presence of independent \\
Governance Index & directors, plus dummy for small board \\
& Mean CF Volatility by two-digit SIC code. CF volatility is measured over previous \\
Industry Sigma & 12 quarters \\
& (Undrawn Credit (from CIQ) + Cash and Investments (1) )/ Total Assets (6) \\
Liquidity & (Market Value of Equity + Total Debt + Preferred Stock Liquidating Value (10) - \\
M/B & Deferred Taxes and Investment Tax Credit (35)) / Total Assets (6) \\
& Stock Price (199) × Common Shares Used to Calculate EPS (54) \\
Market Value of Equity & (Working Capital (179) - Cash and Investments (1)) / Total Assets (6) \\
Net Working Capital/Assets & Operating Income Before Depreciation (13) / Total Assets (6) \\
Profitability & Research and Development Expense (46) / Sales (12) \\
R\&D/Sales & A dummy variable that takes the value of one if the firm is rated by the S\&P, and \\
Rated & zero otherwise \\
Rating & Monthly S\&P ratings (280) \\
Tangibility & Net Property, Plant, and Equipment (8) / Total Assets (6) \\
Total Debt & Debt in Current Liabilities (34) + Long-Term Debt (9) \\
Undrawn Credit / Assets & Undrawn Credit (from CIQ) / Total Assets (6) \\
\hline
\end{tabular}




\section{Table A2}

\section{Representativeness of our sample}

This table provides summary statistics respectively for our sample and the Compustat sample. Our sample consists of non-utilities (excluding SIC codes 4900-4949) and non-financials (excluding SIC codes 6000-6999) U.S. firms covered by both Capital IQ and Compustat from 2002 to 2008. We have removed firm- years with 1) negative revenues, and 2) negative or missing assets. The Compustat sample is obtained by imposing the same filters without the requirement of having coverage in Capital IQ. Table A1 provides a full description of the variables listed below. The last two columns test for differences between samples using the unequal t-test and the two-sample Wilcoxon rank-sum (Mann-Whitney) test.

\begin{tabular}{|c|c|c|c|c|c|c|}
\hline & \multicolumn{2}{|c|}{ Our Sample } & \multicolumn{2}{|c|}{$\begin{array}{l}\text { Compustat } \\
\text { Sample }\end{array}$} & \multicolumn{2}{|c|}{$\begin{array}{l}\text { Test of Difference } \\
\text { Across samples }\end{array}$} \\
\hline & $\begin{array}{c}(1) \\
\text { Mean }\end{array}$ & $\begin{array}{c}(2) \\
\text { Median }\end{array}$ & $\begin{array}{c}(3) \\
\text { Mean }\end{array}$ & $\begin{array}{c}(4) \\
\text { Median }\end{array}$ & $\begin{array}{c}(9) \\
\text { t-test } \\
\text { (p-value) }\end{array}$ & $\begin{array}{c}\text { (10) } \\
\text { MW-test }\end{array}$ \\
\hline Cash/Assets & 0.221 & 0.131 & 0.219 & 0.131 & $\begin{array}{l}-0.957 \\
(0.338)\end{array}$ & 0.046 \\
\hline Size & 1410.3 & 309.8 & 1885.9 & 351.7 & $\begin{array}{c}17.291 \\
(0.000)\end{array}$ & 8.041 \\
\hline Book Leverage & 0.196 & 0.147 & 0.199 & 0.155 & $\begin{array}{c}1.644 \\
(0.100)\end{array}$ & 1.821 \\
\hline $\mathrm{M} / \mathrm{B}$ & 1.676 & 1.303 & 1.664 & 1.274 & $\begin{array}{l}-1.073 \\
(0.283)\end{array}$ & -3.759 \\
\hline Cash Flow/Assets & 0.070 & 0.107 & 0.072 & 0.108 & $\begin{array}{c}1.343 \\
(0.179)\end{array}$ & 2.062 \\
\hline Rating Dummy & 0.263 & 0.000 & 0.225 & 0.000 & $\begin{array}{l}-9.824 \\
(0.000)\end{array}$ & -9.862 \\
\hline Observations & \multicolumn{2}{|c|}{23013} & \multicolumn{2}{|c|}{27741} & & \\
\hline
\end{tabular}


Table A.3

Alternative specifications of target liquidity

This table reproduces Table 2 using different measures of target for each of the three liquidity variables. We only report the coefficients of the target adjustments. All specifications include the same right hand side variables as in Table 2 and year, rating and exchange fixed effects. Robust standard errors clustered at the firm level are reported in parentheses. ${ }^{* *}, * *$, and $*$ denote statistical significance at the $1 \%, 5 \%$, and $10 \%$ levels, respectively.

Panel A: Target computed on average industry liquidity (two digit SIC code)

\begin{tabular}{lccccc}
\hline & $\begin{array}{c}(1) \\
\text { Change in } \\
\text { Liquidity }\end{array}$ & $\begin{array}{c}(2) \\
\text { Change in } \\
\text { Cash }\end{array}$ & $\begin{array}{c}(3) \\
\text { Change in } \\
\text { Credit Lines }\end{array}$ & $\begin{array}{c}(4) \\
\text { Change in } \\
\text { Cash }\end{array}$ & $\begin{array}{c}(5) \\
\text { Change in } \\
\text { Credit Lines }\end{array}$ \\
\hline Liquidity Mean Target Adj. & $-0.357^{* * *}$ & $-0.208^{* * *}$ & $-0.149^{* * *}$ & \\
Cash Mean Target Adj. & $(0.008)$ & $(0.007)$ & $(0.006)$ & \\
CL Mean Target Adj. & & & & $-0.267^{* * *}$ & \\
& & & $(0.008)$ & $-0.416^{* * *}$ \\
& & & & $(0.012)$ \\
\hline
\end{tabular}

$\underline{\text { Panel B: Target computed on average industry liquidity (three digit SIC code) }}$

$\begin{array}{lccc}\text { Liquidity Mean Target Adj. } & -0.350^{* * *} & -0.203^{* * *} & -0.147 * * * \\ & (0.008) & (0.007) & (0.006)\end{array}$

Cash Mean Target Adj.

CL Mean Target Adj.

Panel C: Target computed on average year liquidity

$\begin{array}{lccc}\text { Liquidity Mean Target Adj. } & -0.357^{* * *} & -0.208^{* * *} & -0.149 * * * \\ & (0.008) & (0.007) & (0.006)\end{array}$

Cash Mean Target Adj.

CL Mean Target Adj. 


\section{Table A4}

\section{Predicting Liquidity Levels using Non-Operating Cash}

Replica of Table 3 using non operating cash instead of cash. Non operating cash is measured cash and short term investments (CHE item 1) minus cash (CH item 162). Robust standard errors clustered at the firm level are reported in parentheses. All regressions include a (non-reported) constant, year, rating, and exchange fixed effects. ***, **, and * denote statistical significance at the $1 \%, 5 \%$, and $10 \%$ levels, respectively.

\begin{tabular}{lcccc}
\hline \multicolumn{2}{c}{ Entire Sample } & \multicolumn{2}{c}{ Firms with a Credit Line } \\
& $(1)$ & $(3)$ & $(4)$ & $(6)$ \\
& Non-Operating & Non-Operating & Non-Operating & Non-Operating \\
& Cash/Assets & Liquidity/ Assets & Cash/Assets & Liquidity/ Assets \\
\hline & & & & \\
Size & $0.012^{* * *}$ & $0.004^{* *}$ & $0.006^{* * *}$ & $-0.011^{* * *}$ \\
& $(0.002)$ & $(0.002)$ & $(0.001)$ & $(0.002)$ \\
Book Leverage & $-0.105^{* * *}$ & $-0.063^{* * *}$ & $-0.079^{* * *}$ & $-0.069^{* * *}$ \\
& $(0.010)$ & $(0.010)$ & $(0.006)$ & $(0.010)$ \\
M/B & $0.005^{* * *}$ & $0.003^{* *}$ & $0.009^{* * *}$ & $0.009^{* * *}$ \\
& $(0.001)$ & $(0.001)$ & $(0.001)$ & $(0.002)$ \\
Tangibility & $-0.114^{* * *}$ & $-0.115^{* * *}$ & $-0.049^{* * *}$ & $-0.073^{* * *}$ \\
& $(0.008)$ & $(0.010)$ & $(0.005)$ & $(0.010)$ \\
CF/Assets & $-0.060^{* * *}$ & -0.005 & $-0.062^{* * *}$ & -0.017 \\
& $(0.012)$ & $(0.012)$ & $(0.014)$ & $(0.020)$ \\
NWC/Assets & $-0.146^{* * *}$ & $-0.029^{* *}$ & $-0.085^{* * *}$ & -0.003 \\
& $(0.011)$ & $(0.012)$ & $(0.009)$ & $(0.013)$ \\
Capex/Assets & $-0.046^{* *}$ & $0.055^{* *}$ & -0.008 & $0.104^{* * *}$ \\
& $(0.019)$ & $(0.026)$ & $(0.014)$ & $(0.029)$ \\
R\&D/Sales & $0.004^{* * *}$ & $0.004^{* * *}$ & $0.005^{* * *}$ & $0.004^{* * *}$ \\
& $(0.001)$ & $(0.001)$ & $(0.001)$ & $(0.001)$ \\
Div.Payer & $-0.010^{* * *}$ & $0.021^{* * *}$ & -0.003 & $0.022^{* * *}$ \\
& $(0.004)$ & $(0.004)$ & $(0.003)$ & $(0.004)$ \\
Acqu. Activity & $-0.173^{* * *}$ & $-0.156^{* * *}$ & $-0.085^{* * *}$ & $-0.092^{* * *}$ \\
& $(0.012)$ & $(0.014)$ & $(0.007)$ & $(0.014)$ \\
Industry Sigma & $0.299^{* * *}$ & -0.150 & $0.295^{* * *}$ & -0.067 \\
& $(0.112)$ & $(0.124)$ & $(0.092)$ & $(0.125)$ \\
Observations & 20,807 & 20,807 & 14,376 & 14,376 \\
R-squared & 0.243 & 0.090 & 0.177 & 0.097 \\
\hline
\end{tabular}




\section{Table A5}

\section{Alternative specifications for Table 10}

This table reproduces Table 10 using different measures of target for each of cash and undrawn credit lines. We only report the coefficients of the target adjustments. All specifications include the same right hand side variables as in Table 10 and year, rating and exchange fixed effects. ***,**, and $*$ denote statistical significance at the $1 \%, 5 \%$, and $10 \%$ levels, respectively.

Panel A: Target computed on average industry liquidity (two digit SIC code)

(1)

Change in

Undrawn CL

Cash Mean Target Adjustment

CL Mean Target Adjustment
$-0.004$

(0.003)

$0.088 * * *$

(0.008)
(3)

Change

in Drawn CL

Cash

$0.037 * * *$

(0.006)

Panel B: Target computed on average industry liquidity (three digit SIC code)

Cash Mean Target Adjustment

CL Mean Target Adjustment
$-0.001$

$(0.003)$

$$
(0.003)
$$

$0.038^{* * *}$

(0.006)

Panel C: Target computed on average year liquidity

Cash Mean Target Adjustment

$-0.004$

$(0.003)$

CL Mean Target Adjustment

$0.088 * * *$

$0.037 * * *$

(0.008)

$(0.006)$ 